$9-28-2020$

\title{
CEO-to-Employee Pay Ratio and CEO Diversity
}

\author{
Nazli Sila Alan \\ Katsiaryna Salavei Bardos \\ Natalya Y. Shelkova
}

Follow this and additional works at: https://digitalcommons.fairfield.edu/business-facultypubs Copyright (C) 2020, Emerald Publishing Limited

The post-print version has been archived here with permission from the copyright holder.

\section{Peer Reviewed}

\section{Published Citation}

Alan, Nazli Sila., Katsiaryna Salavei Bardos and Natalya Y. Shelkova. "CEO-to-employee pay ratio and CEO diversity", Managerial Finance 47 No. 3 (2020), pp. 356-382. https://doi.org/10.1108/MF-03-2020-0107

This item has been accepted for inclusion in DigitalCommons@Fairfield by an authorized administrator of DigitalCommons@Fairfield. It is brought to you by DigitalCommons@Fairfield with permission from the rightsholder(s) and is protected by copyright and/or related rights. You are free to use this item in any way that is permitted by the copyright and related rights legislation that applies to your use. For other uses, you need to obtain permission from the rights-holder(s) directly, unless additional rights are indicated by a Creative Commons license in the record and/or on the work itself. For more information, please contact digitalcommons@fairfield.edu. 


\title{
CEO-to-employee pay ratio and CEO diversity
}

\author{
Nazli Sila Alan \\ Fairfield University \\ Katsiaryna Salavei Bardos \\ (corresponding author) \\ Fairfield University \\ kbardos@,fairfield.edu
}

Natalya Shelkova

Gilford College

September 22, 2020

\begin{abstract}
The motivation behind Section 953(b) of Dodd-Frank Act was the increasing pay inequality and supposed CEOs' rent extraction. It required public companies to disclose CEO-to-employee pay ratios. Using the ratios reported by S\&P1500 firms in 2017-18, this paper examines whether companies led by women and minority CEOs have lower ratios than those led by white male CEOs. Results indicate that CEO-to-employee pay ratios are 22-28\% higher for female CEOs compared to their male counterparts, controlling for other determinants of pay ratios. There is, however, no statistically significant difference between the pay ratios of minority vs. white male CEOs. Minority female CEOs have lower CEO-to-employee pay ratios than White female CEOs. Consistent with literature, larger and more profitable firms have higher CEO-to-employee pay ratios.
\end{abstract}

\section{Keywords}

CEO-to-employee pay ratio, Pay ratio, Dodd-Frank Act, Section 953(b), Executive compensation, Median employee pay, Female CEO compensation, Minority CEO compensation 


\section{Structured Abstract}

\section{Purpose}

The motivation behind Section 953(b) of Dodd-Frank Act was the increasing pay inequality and supposed CEOs' rent extraction. It required public companies to disclose CEO-to-employee pay ratios. Using the ratios reported by S\&P1500 firms in 2017-18, this paper examines whether companies led by women and minority CEOs have lower ratios than those led by white male CEOs.

\section{Design/methodology/approach}

This paper uses multivariate regression along with a matched sample analysis to examine whether female and minority CEOs have higher CEO-to-employee pay ratios compared to male and white CEOs, controlling for other determinants of pay ratios.

\section{Findings}

Results indicate that CEO-to-employee pay ratios are 22-28\% higher for female CEOs compared to their male counterparts, controlling for other determinants of pay ratios. There is, however, no statistically significant difference between the pay ratios of minority vs. white male CEOs. Minority female CEOs have lower CEO-to-employee pay ratios. Consistent with literature, larger and more profitable firms have higher CEO-to-employee pay ratios.

\section{Originality/value}

While prior studies on determinants of CEO-to-employee pay ratios have used either industrylevel or self-reported data for a small subset of firms (resulting in selection bias), this paper uses firm-level data that is available for all S\&P 1500 firms because of new disclosure requirements due to the Dodd-Frank Act Section 953(b). Moreover, this is the first paper to test whether gender or ethnicity of a CEO affects within-firm pay inequality.

\section{Keywords}

CEO-to-employee pay ratio, Pay ratio, Dodd-Frank Act, Section 953(b),, Executive compensation, Median employee pay, Female CEO compensation, Minority CEO compensation 


\section{Introduction}

Inequality is a growing concern for many parties, including policy makers, politicians, academics, business leaders and media. In fact, a chief economist at Deutsche Bank views growing inequality to be the top risk for the market for $2020 .{ }^{1}$ Concerns about overall income inequality and supposed CEOs' rent extraction motivated Section 953(b) of Dodd-Frank Act. This legislation enacted in 2015 requires public companies to disclose the median employee pay and its ratio to CEO pay, beginning with fiscal year 2017.

Compensation of women and minorities, including in leadership positions, is another area that now receives considerable attention. There is an ongoing academic debate on whether women and minorities in leadership roles are underpaid (as in recent papers by Leslie et al., 2017; Gupta et al., 2018; and Field et al., 2019). A smaller, emerging area of empirical research, looks at whether female CEOs affect compensation of employees (e.g., Magda and Cukrowska-Torzewska, 2018), however, with little attention thus far to similar roles played by minority executives.

Given the saliency of the topic of executive compensation coupled with discrimination, most of the prior research (see further discussion) in the area had focused on resolving the conflict between a potential gender, race and ethnicity bias in compensation, resulting in lower executive pay of these groups, and purposeful fulfillment by corporations of strategic "diversity goals", which increases their demand and results in higher pay. Our paper, by utilizing newly available data on relative pay of the top executives to their employees, collection of which was mandated by the Dodd-Frank, attempts to uncover a more nuanced picture of the interplay between CEO's gender/race/ethnic background and employee compensation within large US corporations. By looking at the CEO-to-median-employee pay ratio, we examine whether the CEO background

\footnotetext{
${ }^{1}$ https://www.cnbc.com/2019/11/09/here-are-the-biggest-risks-to-the-financial-markets-in-2020.html
} 
affects the size of this ratio, potentially moving corporate compensation systems towards greater equity, given hypothesized differences in values and management style of female and minority CEOs from the white male majority.

Because the data on median employee pay has not been publically available prior to this legislation, academic research on the determinants of CEO-to-employee ratio has been limited and suffers from various data issues. Papers on CEO-to-employee ratio use various sources of such data: proprietary data based on employee surveys (Mueller et al., 2017; Green and Zhou, 2019; Cheng et al., 2017; Elkin, 2016); self-reported labor costs adjusted for pay of top 5 executives reported by 10\% of firms (Faleye et al., 2013; Balsam et al., 2019); industry level compensation data from the U.S. Bureau of Labor Statistics (Balsam et al., 2019).

Two papers examined determinants of CEO-to-employee pay ratio. Mueller et al. (2017) finds that firms with higher pay inequality are larger, have higher valuation, stronger operating performance, greater equity returns and more earnings surprises. They interpret their findings as suggesting that pay inequality is not priced-in, and reflects the ability of firms with high inequality to secure top talent at the executive level. The paper uses proprietary data set of UK firms for 2004-2013 years, and excludes information on overtime, bonus, or incentive pay. This data is collected through a survey, and potentially suffers from a selection bias due to the fact that the firms with abnormally high or low pay not taking part in the survey. The authors also find that wages in their sample are higher than the national average and are more right-skewed. The results also cannot be generalized to the US because the pay ratio in UK is much smaller than in the US (in 2017 the ratio in the UK was 167:1 and 312:1 in the US). ${ }^{2}$

\footnotetext{
${ }^{2}$ https://www.cebglobal.com/talentdaily/ceo-employee-pay-gaps-widen-in-us-and-uk/
} 
Faleye et al. (2013) examines the determinants of the CEO-employee pay ratio and its effect on employee behavior and performance. They find that the pay ratio increases with the bargaining power of the $\mathrm{CEO}$, and it is higher in homogeneous industries where employees are more interchangeable and less powerful. They also find that the pay ratio declines with employee unionization and capital intensity, however find no relation between relative pay and employee productivity, except for a sub-sample of firms with fewer employees ${ }^{3}$, for which they find a positive relation. They also regress Tobin's Q, change in Tobin's Q, and ROA on CEO-pay to find a coefficient that is positive and significant. The main problem with this study is its sample, limited to companies in ExecuComp database, which voluntarily reported total labor expenses at the time when such disclosure was not required. This introduced a sample selection bias and limited the sample to only 450 firms, with financial services industry being over-represented, while manufacturing industry - under-represented when compared to the ExecuComp universe. Their sample firms were also larger. The dataset in this paper contains compensation of the median employee while Faleye et al. (2013) estimated that number as total labor expenses reported in Compustat less total executive compensation from ExecuComp (reported for the top five executives), divided by the number of employees. This estimate might be inaccurate for firms with many highly paid executives beyond the top five.

Prior research finds that gender and ethnicity are characterized by unique management style (e.g., Kaplan et al., 2012; Newton and Simutin, 2015). This paper examines whether CEOto-employee pay ratios differ for female CEOs and minorities. To the best of our knowledge, no prior literature had addressed this question.

\footnotetext{
${ }^{3}$ Small number of contestants at such firms should strengthen tournament incentives.
} 
Growing global exposure of US corporations, increasing population diversity in the US, and greater participation of women in the labor market pushes public firms to seek leadership that is increasingly more diverse. Moreover, the diverse leadership viewed more broadly as potentially able to address the issues of growing social inequality, which is partly due to the crisis of corporate governance and rapidly growing executive compensation. By looking at whom they called the New CEOs of Fortune 500 companies, Zweigenhaft and Domhoff (2010) note that the number of "minority" CEOs (women, African Americans, Latinos, and Asian Americans) has grown significantly in recent years. From 2000 to 2008 , the number of F500 women and minority CEOs climbed from 21 to 37 , representing $2 \%$ of the total number at the end of this period. Our more recent data from 2017-2018 shows that the number of women and minority CEOs has climbed further, with women representing now 5\% of all S\&P1500 CEOs, and representation of minority groups being at $7 \%$.

These developments have multiple and important implications for CEOs compensation, corporate compensation systems, and overall pay inequality, both in the short and the long term, which are at the root of our research question. Female and minority CEOs, given their background, are more likely to have "softer" management style and approach to personnel issues (see further discussion), thus expected to be closing the inequality gap. However, these predictions may not manifest themselves in the near term. The surge in demand for "diversity" CEOs may lead to a spike of their compensation, thus not allowing the closure of the inequality gap. Additionally, due to the labor market discrimination that minority executives are a subject to, only the "brightest star" representatives of this group can reach the top of the corporate ladder which may explain their greater productivity, leading to their greater compensation. The complexity of these issues 
makes it an empirical question how female and minority CEO presence is associated with CEOto-employee pay ratio.

Controlling for other determinants of CEO-to-employee pay ratio, our results indicate that there is a positive association between CEO-to-employee pay ratio for female CEOs, but no relation for minority CEOs is found when the full sample is analyzed. According to our estimates, CEO-to-employee pay ratios are $22-28 \%$ higher for female CEOs when compared to their male counterparts. It is also shown that larger and more profitable firms have higher CEO-to-employee pay ratios. This result is consistent with findings of Mueller (2017) and Faleye et al. (2013). When we restrict the sample to only female CEOs, we find both in univariate and multivariate analysis that minority female CEOs have lower CEO-to-employee pay ratios than Caucasian female CEOs. ${ }^{4}$ We do not find differences in the pay ratios, CEO and employee compensation between male minority and male Caucasian CEOs.

This is the first paper to examine the association of the presence of female or minority CEOs on CEO-to-employee pay ratios. The paper demonstrates that gender helps explain CEOto-employee pay ratio after controlling for firm, industry and CEO characteristics, despite a small sample size of female CEOs. The paper contributes to the examination of the determinants of the CEO-to-employee pay ratio, which is also studied by Faleye et al. (2013) and Mueller et al. (2017). None of these studies looked at gender or ethnicity of the CEO. The examination of the pay gap is important giving a growing concern regarding pay inequality within firms. In fact, the CEO-toemployee pay gap has increased from 20-to-1 in 1996 to 202-to-1 in 2017-2018. ${ }^{5}$ The rest of the

\footnotetext{
${ }^{4}$ Interestingly, both the CEO compensation and the employee compensation is higher for minority female CEOs, although only employee compensation difference is statistically significant for the log of the employee compensation. The lack of statistical significance for CEO compensation could be due to small sample size.

${ }^{5} 1965$ data is from Economic Policy Institute: https://files.epi.org/pdf/130354.pdf. 2017-2018 data is from our analysis.
} 
paper is organized as follows. Section 2 further reviews the literature and develops the hypotheses. Section 3 describes the data. Section 4 discusses the results and Section 5 concludes the paper.

\section{Literature review and hypothesis development}

The hypothesis tested in this paper are whether firms headed by female and minority CEOs have higher/or lower median-employee-to-CEO compensation ratio. Thus, we review the available literature on the ratio, followed by the review of theories that may explain the differences in the ratio for the "minority" and the "majority" executives.

\subsection{Literature on CEO-to-worker pay ratios}

To the best of our knowledge, only two other papers use the CEO-to-worker pay ratio disclosed following enactment of Dodd Frank Act. Bardos et al. (2020) examine the association between the cost of debt and CEO-to-employee pay ratio and find a negative relation while controlling for covariates and endogeneity. This result is the strongest in financially constrained, labor intensive, and small-to-medium sized firms. Jung et al. (2018) examine pay ratio for 1,125 S\&P 1500 firms. They differentiate between required and supplementary pay ratios (with 14\% of the firms in their sample provide a complementary pay ratio) to test which firms are more likely to disclose supplementary pay ratio. For $86 \%$ of these firms' supplementary pay ratio is lower than required.

There is a body of prior research papers that examines CEO-to-employee pay ratios, with majority of work concentrating on relationship between the ratio and the firm performance. However, all of them use other sources of data: earlier proprietary data based on employee surveys, self-reported labor costs or industry level compensation data from the U.S. Bureau of Labor Statistics. 
Rouen (2019) constructs firm level pay ratio from establishment-level annual compensation data provided by the U.S. Bureau of Labor Statistics (BLS) to examine its relationship with firm performance. His dataset covers $40.3 \%$ of ExecuComp firm-year observations for the 2006-2013 period. The author finds no relationship between the pay ratio and firm's accounting performance measured by industry-adjusted return on net operating assets. However, he finds negative relation between unexplained pay disparity and future firm performance, explaining it by weak corporate governance in firms with overpaid CEOs and underpaid employees, and substantial employee turnover.

Green and Zhou (2019) use data from the Glassdoor.com (which contains over 900 thousand salaries and one million employee-authored company reviews for more than 1,200 public US firms) to examine the relationship of pay inequality to employee morale. They find that the within-firm base pay inequality is negatively associated with employee morale, while the total pay inequality is positively associated with morale; the low base pay inequality corresponds with employer reviews that emphasize fairness and commitment; and the base pay inequality is negatively related to firm performance with no significant relation for total pay inequality.

Cheng et al. (2017) use a proprietary dataset of 817 firms containing firm-level worker pay data, obtained from PayScale.com (which primarily gathers compensation data directly from workers) to examine association between the pay ratios and the firm value. The web service applies proprietary algorithms to assure the consistency of the data and complements its data collected from employees with both publicly and privately available data sources to ensure its accuracy. ${ }^{6}$ They hypothesize that higher CEO pay ratios reduce employee morale and productivity, reflecting CEO rent extraction in firms with weak corporate governance. Alternatively, high pay ratios may

\footnotetext{
${ }^{6}$ http://www.payscale.com/about/methodology
} 
also indicate that the firm had secured a more talented CEO. They find that firms with higher CEO pay ratios have higher market value, as measured by one-year ahead Tobin's Q and ROA. The paper also examines the relation between CEO pay and shareholder value creation through acquisitions and CEO turnover-performance sensitivity. They find a positive relation between the pay ratio and abnormal stock returns surrounding acquisition announcements, which they argue captures the quality of acquisitions. They note that the sensitivity of CEO turnover to firm performance increases with the CEO pay ratio, which they argue is inconsistent with the CEO entrenchment argument. They interpret this finding as suggesting that high CEO pay ratios are not symptomatic of governance failures. Further, they find weak evidence that the pay ratio and firm value are positively related for better governed firms, refuting the pay-for-luck explanation. While the authors' results are informative, the size of their data set, as well as that fact that the pay information is self-reported pose may result in potential biases.

Balsam et al. (2019) use both the Compustat and the ExecuComp databases to examine an association between CEO pay ratio and firm value and find it to be concave and dependent on firm characteristics. They use the same self-reported measure of compensation as Faleye et al. (2013) for their main measure. Their alternative measure is the industry-level worker pay from the Bureau of Labor and Statistics. Balsam et al. (2016) provide international evidence, suggesting that a country culture is an important determinant of the CEO pay ratio. In turn, they use self-reported total staff expenses per employee to construct their CEO pay ratio, hence their study suffers from sample selection bias.

Elkin (2016) assesses compensation system structure using a promotional pay ladder (PPL), which measures how percentage increases in compensation correspond to increases in employee responsibility. The paper uses data on 371 firms (members of S\&P 500) from 
SalaryList.com, which compiles government- and firm-disclosed salaries, and has firm, year, and location specific information. It finds that firms with "unequal" PPL are associated with lower future economic performance. The paper, however, suffers from certain potential biases: one associated with firms' voluntarily disclosure of salary information (likely to disclose only beneficial salaries); and another one associated with using larger firms in terms of assets, market value of equity, sales, and employees than the rest of the S\&P 500 firms.

Uygur (2019) finds positive association between pay ratio and firm performance and payperformance sensitivity, however only when you pay more to a high-ability CEO. He also finds that the pay-performance sensitivity weakens when a low-ability CEO is paid more. The positive association between the pay ratio and firm performance weakens with a chair-CEO.

Crawford et al. (2018) finds that shareholders' say-on-pay (SOP) votes are related to the pay ratio. In particular, they find that voting dissent on SOP proposals is increasing in the level of the pay ratio, particularly for banks in the highest pay ratio decile. However, this study analyzes only U.S. commercial banks, hence their results might not be generalizable. ${ }^{7}$ Like Faleye et al. (2013), Crawford et al. (2018) compute their pay ratio as the ratio of CEO pay to total compensation expense less compensation of the five highest-paid executives scaled by the total number of employees. This measure is missing for many companies and is not be a good proxy for median pay in industries with large number of other highly compensated senior employees.

An older study by Cowherd and Levine (1992) found that a smaller disparity between top management and workers' pay is associated with higher product quality. Cullen and Perez-Truglia (2018) survey 2,060 employees of a billion-dollar company and examine misperceptions about

\footnotetext{
${ }^{7}$ They use SNL Bank/Thrift Premier database, which contains both financial statement and CEO compensation data collected from SEC filings.
} 
salaries. They find that perceived management and peer salaries have effect on behavior of employees, with higher perceived peer salary decreasing effort, output and retention, while higher management salary having the opposite effect. The study has limited generalizability because it studies employees of a single company. In a subsequent paper, Cullen and Pakzad-Hurson (2019) develop a wage-bargaining model and use data from online markets for low-skill temporary jobs to find that greater pay transparency may lower overall wages, while reducing within-firm pay inequality. It also promotes hiring and improves profitability.

Several papers examine the effect of the pay ratios on the cost of debt, finding mixed results. Huang et al. (2018), using Compustat data on average labor cost, find a positive relation between the CEO-employee pay ratio and bond yield spreads, which is more pronounced for financially constrained firms. Lei (2017) uses industry mean wage rates provided by the Bureau of Labor Statistics to show that a higher CEO-to-worker pay disparity is associated with lower cost of debt (and a higher probability of credit rating upgrades). The result is more pronounced for the labor-intensive firms than for the capital-intensive ones.

Johnson (2018) examines whether the mandated disclosure of CEO-to-employee pay ratios motivates firms to curb CEO pay. He finds no evidence of the curb on unexplained CEO pay changes in response to the SEC's proposal (or adoption) at the average firm. He does find evidence of the curb in response to the SEC's proposal (but not adoption) at select firms that are more sensitive to the reputational effects of the rule. As already discussed, Bardos et al. (2020) finds negative association between CEO-to-employee pay ratio and the cost of debt for S\&P 1500 companies.

There is also literature that examines the implication of the pay gap between CEOs and other top management rather than an average employee. Kini and Williams (2012) argue that large 
gap between CEO pay and the pay of the next layer of senior managers provides tournament incentives. They find that significantly positive relation between firm risk and tournament incentives. Liu and Jiraporn (2010) also examine CEO compensation relative to the next five highest paid executives in the firm and find that it corresponds with lower credit ratings and higher yield spreads. Using similar measure, Huang et. al. (2019) find a positive association between CEO pay disparity and yields on seasoned debt.

There is also some international evidence. Kiatpongsan and Norton (2014) uses a survey data from 40 countries and find that ideal pay gap is much smaller than estimated pay gap. They also find that people significantly underestimate actual pay gap. In the US, the study finds that the CEO-to-worker pay ratio is $354: 1$, but is estimated at 30:1, compared to the ideal ratio of 7:1.

For the sample of Korean firms, Shin et al. (2015) finds a negative association between operating and stock returns and the pay ratio. They also find that performance effects of the executive pay multiple are likely to be influenced more by deviations from the expected executive pay multiple. However, these results might not be generalizable to the US where pay ratio is much higher. ${ }^{8}$

For a sample of Chinese firms, Xu et al. (2017), Zhao et al. (2019), and Gu and Yang (2018) find a positive effect of the pay gap on innovation, while Dai et al. (2017) find that productivity is an inverted-U function of the pay ratio. Jiang et al. (2019) find that the compensation gap in a company run by a chairperson from a collectivistic culture tends to be smaller than that of a company run by a chairperson from an individualistic culture. This effect is stronger if the chairperson has a longer tenure.

\footnotetext{
${ }^{8}$ They report a maximum ratio of just 46.82 .
} 
Dittmann et al. (2018) find that employee wages are increasing in CEO compensation for a sample of German firms. They find that the firm wage gap is incorrectly priced only by unsophisticated traders, and that some investors prefer firms with low pay inequality which decreases the cost of capital for firms that adopt equitable pay schemes.

\subsection{Women and minority CEOs' compensation literature and hypothesis development}

In order to answer our research question, we need to understand the factors that determine both the CEO's and the median employee's pay. First, we acknowledge that markets and paysetting environments differ substantially for CEOs and employees of large public corporations, in terms of market competition, pay-setting methods, and structure of compensation packages (see for ex., Rosen 1981). The market for CEOs is, in relation to the market for "ordinary" employees, a smaller market "for superstars", as companies compete for CEO's unique set of talents that can closely meet company's specific managerial needs, which commands a pay premium (see for ex., Falato et al., 2012). Thus, the CEO compensation is driven not only by industry characteristics, as employee pay would, but rather by a CEO's individual characteristics and their "fit" with a specific company. The market for ordinary employees is greater and certainly more competitive, with each employee being more "replaceable". Thus, the median employee pay, while industry- and company-specific, is not necessarily tied to the unique characteristics of an employee.

The pay-setting methods for CEOs and ordinary employees differ substantially as well, which may further help to explain the differences in pay. While both employee and executive markets are driven by the overall "market forces", CEO compensation is set by corporate boards composed of external members, while employees' pay is mainly determined internally. The structures of compensation packages differ because of these dissimilarities, as well as due to incentives built-in in the compensation, with CEO compensation tied more directly to company 
performance. Such differences in market structure and pay-setting is reflected in the data. For instance, our sample standard deviation of the annual CEO compensation exceeds 9 million dollars, while the standard deviation of the median employee pay is approximately 46 thousand dollars. Also, the median employee pay is somewhat similar among the identified groups regardless of the CEO background.

Therefore, to address the research question at hand and to decompose the CEO-to-medianemployee pay ratio, this paper pays particular attention to the CEO characteristics while controlling for industry-specific factors that also affect employee pay. In particular, we attempt to decipher whether gender and minority status of the CEO affects the size of the ratio.

Re-phrasing our research question, we look for systematic differences in pay ratios between majority (white, male) CEOs and the CEOs who are women and/or representative of a minority group.

Hypothesis 1: Companies with minority and female CEOs have lower CEO-to-medianemployee pay ratio.

We suggest that there are at least two explanations why this could be the case. First, female and minority CEOs may hold different attitudes, values and approaches towards social corporate responsibility in the area of compensation due to their unique life experiences. They may hold beliefs that a lower pay gap between executives and employees improves employee morale and is associated with better financial performance (long- and short-term).

There is a body of literature devoted to differences in management styles of women CEOs. There is a smaller number of studies devoted to management style of CEOs who are racial and ethnic minorities CEOs. Rosener (1990) notes that women's management style is transformational, rather than transactional. In a series of interviews with female executives she learned that when 
leading, women attempt to "enhance other people's sense of self-worth and to energize followers", making subordinates feeling good about themselves. Women are more likely to use soft skills to manage, rather than a hierarchical approach (Kaplan et al., 2012).

Researchers have acknowledged that fulfilling employees' social emotional needs and acting on their behalf according to notions of distributive justice affects firm performance (Feng et al., 2015). Presence of a female top executive can indicate that an organization is female friendly, follows affirmative action policies, or egalitarian (Shin 2012). A meta-analysis conducted by Seung-Hwan and Harrison (2017) shows that having female CEOs are associated with (weakly) better long-term firm performance and (weakly) worse stock market performance in the short run, which may contribute to lower pay of female CEOs.

It is fair to expect that the management style would directly translate into approach to compensation, though literature in this area is limited. In a recent paper Magda and CukrowskaTorzewska (2018), using Polish data for private and public sector companies, show that having female managers is associated with a smaller male-to-female pay gap. Flabbi et al. (2019), using Italian manufacturing data from 1980-1997, found that female leadership has a positive impact at the top of the female wage distribution and a negative impact at the bottom. Cardoso and WinterEmber (2010), using Portuguese data find that female firm managers are associated with higher wages for female employees.

In addition to promoting fair pay for employees, female and minority CEOs are less likely to engage in opportunistic behavior and "extract concessions" (Mishel and Wolfe, 2019), or to perform contract- or power-rigging than white male CEOs (Marisetty et al., 2016).

Research on leadership styles of executives who are racial or ethnic minorities underscores that cultural background matters. Somewhat similar to the views on female leadership, it is found 
that "ethnic minorities $[\ldots]$ tend to adopt a nurturing, inclusive, dynamic, engaging and inspiring leadership style that falls under the umbrella of "transformational leadership", and black supervisors as seen as giving more support to their subordinates than white (see literature survey by Okozi et al., 2009), potentially promoting greater within-firm pay equality.

Previously mentioned studies by Balsam et al. (2016) and Jiang et al. (2019) also underscore that culture matters when it comes to relative compensation of corporate executives and employees. Balsam and co-authors, using international evidence, "find that the CEO-worker pay ratio is positively associated with power distance and masculinity of the national culture and negatively with uncertainty avoidance and long-term orientation". Jiang and co-authors, using Chinese data on a chairperson's place of birth, propose that the compensation gap between managers and workers is affected by culture, traditions, as well as by institutional and legal factors. Thus, one can expect differences in relative compensation of racial and ethnic minority and employees versus white majority CEOs.

While values and leadership style of women and minority CEOs can lead to their actively affecting the CEO-to-employee pay ratios towards greater equity (reducing the ratio), racial and gender bias and discrimination may also be associated with lower ratios, with the CEO "being affected", not "affecting" the ratio.

While the overall gender and minority pay gap has been showed to gradually close (e.g., Blau and Kahn, 2017, Joshi et al., 2015), there is numerous evidence that women and minorities in leadership are underpaid. Thus, discrimination is one of the factors which constitutes our second potential explanation of the lower CEO-to-employee pay ratio. For instance, Bertrand and Hallock (2010) find that $25 \%$ of the $45 \%$ gender pay gap among top 5 corporate executives is unexplained (using ExecuComp data from 1992-1997), thus suggesting discrimination. Renner et al. (2002) 
also find that an "unexplained gender gap in executive pay exists in the performance-based components of compensation packages". Thus, having a negative sign on the female/minority dummy while controlling for all other characteristics, will indicate discrimination.

Executives who are gender and ethnic minorities still face systemic biases due to preexisting stereotypes of persona of the CEO (Hill et al., 2015). They may face substantial obstacles while climbing the corporate ladder (e.g., Blau and Devaro, 2007), be subject to extra scrutiny when undergoing assessment (e.g., Haslam and Ryan, 2008), and their successful performance can be attributed to factors other than their competence (e.g., Greenhaus and Parasuraman, 1993). We further discuss literature on bias in compensation in the next section.

Hypothesis 2: Companies with minority and female CEOs have higher CEO-to-medianemployee pay ratio.

Higher CEO-to-employee pay ratio can be due to higher demand for female and minority executives and, therefore, result in higher pay. Additionally, research suggest that female or minority CEOs can be hired in "glass cliff" or precarious economic conditions, being called (and paid) to turn around corporate fortunes, which may entail budget and compensation cuts.

Higher demand for female and minority CEOs could be due to their superior on-the-job performance, or due to strategic objectives by corporations to diversify their workforce, including leadership, in order to earn public recognition in this area. Female and minority CEOs could be more productive due to their superior ability to connect with increasingly more diverse customer and/or employee base. They bring a unique set of talents to firms and create competitive advantage, resulting in superior performance, according to the resource-based "theory of competitive advantage" (Barney, 1991). They are also viewed as having passed an intensive selection process 
and successfully climbed the corporate ladder, thus representing the top talent in their gender or ethnic group.

Jalbert et al. (2013), using Forbes CEO data combined with Compustat from 1997 to 2006, find that female CEO's produce higher sales growth and higher returns on investments and assets; their firms also have higher stock market valuations. Wolfers (2006), examining S\&P1500 data, finds that women-CEOs at least do not underperform men. Smith et al. (2005), using Danish data, show that management diversity in general (women in top management positions) positively affect firms' performance. Flabbi et al. (2019), using Italian manufacturing data from 1980-1997, also find that female leadership has a positive impact on firm performance, particularly on sales. Keloharju et al. (2016), using Swedish data, show that women who attain an executive position are generally better qualified than men.

When it comes to relative pay of female chief executives, there is an emerging body of literature devoted to the phenomenon of female pay premium. Studies that find the female premium are Gayle et al. (2012), Hill et al. (2015), Leslie et al. (2017), among others. Gayle et al. (2012) use 2006 ExecuComp data supplemented by Compustat and stock price data to show that while women executives are paid more, no gender pay gap is present when controlling for executives' rank. Hill et al. (2015) use Compustat's ExecuComp 1996-2006 data to investigate whether minority, female and ethnic CEOs have compensation and likelihood of job exit that is different from white male CEOs. They find that minority status CEOs benefit from the value, rarity and inimitability manifested in higher compensation, suggesting that bias does not play a role at the apex of the corporate ladder. They also find that female CEOs have a lower likelihood of job exit, while ethnic minority CEOs have a higher likelihood. Leslie et al. (2017), looking at "high potential" women in S\&P 1500 companies from 1992 to 2006, also support the resource-based 
theory, pointing out that strategic human resource management with the goal of diversifying top management results in higher pay for women.

However, verdict on existence of the female executive pay premium is not final, and there exists equally strong evidence that shows no difference between pay of male and female executives when accounting for a broad range of controls. Such studies include Adams et al. (2012), Budeja et al. (2012), Gupta et al. (2018), among others. Adams et al. (2007), using ExecuComp database of executives at 1,500 large US corporations from 1997 to 2004, confirm that top women executives are compensated similarly to men. Budeja et al. (2012), using 291 US firm-years for the period of 1998-2010, do not find any association between CEO pay and gender. More recently, Gupta et al. (2018) replicated the study by Hill et al. (2015) using a larger sample of firms and more rigorous empirical analysis, also revealing no differences in compensation between male and female CEOs. Internationally, Geiler and Renneboog (2015), using UK data, find that female CEOs also do not experience the gender pay gap (though they report that lower-level female executives do).

While research on gender diversity and corporate board diversity is numerous, studies of performance of CEOs who are racial and ethnic minorities are extremely sparse. One of the few papers in this area by Cook and Glass (2014), suggests that minority CEOs are more likely to be promoted in strongly performing firms. Evidence that minority CEOs affect (positively or not) firm performance is lacking.

An explanation of female or minority CEOs being hired during precarious economic conditions, a hypothesis known as "the glass cliff”, is discussed among others by Ryan and Haslam (2007) in their review of archival and experimental evidence of promotion of female executives. More recently, Glass and Cook (2019) also explore promotions of both gender, and racial and 
ethnic minorities. Interestingly, the latter find evidence that in order to achieve upward mobility, women and minority leaders pay a significant risk tax, which could also lower their pay (and ratios), which in fact adds to a list of possible explanations of the lower ratio, as one of the "bias" factors.

\section{Data}

The data on CEO-to-employee pay ratio is obtained from MyLogIQ, who collected the data from Schedule 14A. Companies provide the data on CEO pay and the pay of median employee. Often companies also provide the discussion of how median employee is identified. The data is available for 2017 and 2018 fiscal years for S\&P 1500 companies. Company characteristics are obtained from Compustat. CEO characteristics and pay is obtained from ExecuComp and Institutional Shareholder Services - ISS (previously called RiskMetrics). Returns come from CRSP. Variables are defined in Table 1.

MyLogIQ dataset provides CEO-to-employee pay ratio for 2550 firm-year observations: for 1181 firms in fiscal year 2017 and 1369 firms in 2018. For 1140 of these firms, pay ratios are available for both 2017 and 2018 fiscal years. Matching the data on pay ratios to the CRSP/Compustat Merged database (CCM), we collect accounting and stock price data for 2543 of the observations. We further match the sample to ExecuComp which yields an overall sample size of 2520 over the two-year sample period, for 1397 unique companies. Further merging the data with ISS reduces the sample size to 1910 (from 2520), therefore we rely on ExecuComp for the primary variable of interest (CEO Gender).

Table 1 provides a list of the variables along with their definitions and sources. CEO Compensation and Median Employee Compensation are measured in actual dollars, and the Pay Ratio is calculated by dividing the CEO Compensation to the Median Employee Compensation. 
Female is a dummy variable that equals 1 if the CEO is female, and 0 otherwise. Duality is another dummy variable that equals 1 if the $\mathrm{CEO}$ is also serving as the Chairman of the Board, 0 otherwise. Tenure is the number of years since the current CEO took office. Minority is created as a dummy variable using the Ethnicity variable of the ISS database; it equals 0 if the ethnicity of the CEO is Caucasian, 1 otherwise. ${ }^{9}$ Size of the firm is measured as natural log of the firm's total assets (AT). $\mathrm{B} / \mathrm{M}$ is the book-to-market ratio calculated as the book value of equity divided by market value of equity (CSHO*PRCC_F) ${ }^{10}$ ROA is the return on assets, calculated as the ratio of income before extraordinary items (IB) divided by prior year total assets (AT). Tobin's Q is measured as the market value of equity (CSHO*PRCC_F) plus book value of liabilities (LT) plus preferred equity redemption value (PSTKRV), divided by total assets (AT). PCI is the physical capital intensity measured as net property, plant, and equipment (PPENT) divided by the number of employees (EMP).

\section{Results}

Table 2 presents summary statistics, for compensation variables in Panel A, and for all variables by Gender and Ethnicity in Panel B. As seen in Panel A, the median CEO makes $\$ 6.4$ million while the median employee earns about $\$ 62 \mathrm{~K}$. CEO-to-employee pay ratios range from 5.5 at the lowest percentile to 1794.6 at the highest percentile, with a 201.6 mean ratio.

\footnotetext{
${ }^{9}$ Other ethnicities reported on ISS database are Asian, Hispanic/Latin American, Indian, Middle-Eastern, and Black/African American in order of descending frequency in the sample.

${ }^{10}$ We calculate book equity following Davis et al. (2000). Therefore, book equity is measured as shareholders' equity (see SE calculation next), plus balance-sheet deferred taxes and investment tax credit (TXDITC) if available, minus the book value of preferred stock (see PS calculation next). SE is set equal to, depending on availability, stockholders' equity (SEQ), or common equity (CEQ) plus the carrying value of preferred stock (PSTK), or total assets (AT) minus total liabilities (LT) in that order. PS is set equal to, depending on availability, redemption value (PSTKRV) if available, or liquidating value (PSTKL), or carrying value (PSTK) of preferred stock, in that order (or 0 if none of them are available).
} 
Looking at the gender breakdown in Panel B of Table 2, it is seen that out of the 2520 firm year observations with available data on CEO gender, $134(5.3 \%)$ are female. Their pay ratio is 373.88 compared to 191.98 for male counterparts, with the difference being statistically significant at $1 \%$ level (see Panel D for tests of statistical significance). Minorities account for $7 \%$ of sample with available data. Their pay ratio is 172.7 compared to 203.4 for the Caucasian sample. This difference is statistically significant at $10 \%$ level when a t-test assuming unequal variances is used (t-stat assuming equal variances is 0.98 ) - see Table 2 Panel D. Winsorized and trimmed samples show similar differences.

Female CEOs in the sample earn on average $\$ 10.8$ million, while male CEOs earn about $\$ 8.5$ million. For minority vs. Caucasian CEOs, there is not much difference in means, with both groups earning an average $\$ 8.5$ million. Median employee compensation, on average, is lower in firms with a female CEO (\$68K vs. \$71K); but higher in firms with minority CEOs (\$75K vs. $\$ 70 \mathrm{~K})$. The gender and ethnicity breakdown in Panel C of Table 2 further shows that $8 \%$ of female CEOs and $7 \%$ of male CEOs are a minority.

Panel C of Table 2 provides further breakdown of the sample. It shows that minority female CEOs have lower pay ratio (207.96 versus 391.29 for Caucasian female CEOs). This difference is statistically significant when unequal variance t-statistic is calculated (see Table 2 Panel D). ${ }^{11}$ Interestingly, although the CEO-to-employee pay ratio is lower, both the CEO pay and the employee pay is higher for minority female CEOs. They earn $\$ 12.5$ million compared with $\$ 10.7$ million for Caucasian female CEOs. However, this difference is not statistically significant, potentially due to small sample size for minority female CEOs (Table 2, Panel E). The average employee compensation is $\$ 84 \mathrm{~K}$ for minority female CEOs and $\$ 67 \mathrm{~K}$ for Caucasian female CEOs.

${ }^{11}$ Female subsample pay ratio comparison test is included again in Table 8 to have the female subsample results together. 
This difference between the logs of employee compensation is statistically significant. Table 2 , Panel E reveals little difference in CEO compensation, employee compensation and CEO-toemployee pay ratio among male Caucasian and minority subsamples.

Among female CEOs 33\% also serve as Chairwomen of their Board, while $42 \%$ of male CEOs have this dual title (see Table 2, Panel B). Average tenure of a female CEO is 5.5 years, whereas male CEOs have been in office for 8.5 years on average. Firm characteristics such as firm size, B/M, ROA, Tobin's Q, and PCI are largely comparable between the firms led by female vs. male CEOs.

To visualize the pay ratio difference between male and female CEOs, Figure 1 depicts a histogram comparing the fraction of the log pay ratios for male vs. female CEOs. Small sample size for female CEOs do distort the look of the distribution, but it is still visible that the pay ratio for female CEOs has some extreme positive outliers while male CEOs' pay ratio is more normally distributed. Similar graphical analysis for minority CEOs (available upon request) shows a higher density of minority CEOs in mid-range of the ratio distribution, while Caucasian CEOs are more likely to have high extreme values. It is also worth noting that both female and minority CEOs are somewhat underrepresented on the lower end of the distribution suggesting that they are hired by larger (and better paying firms) that can afford to pursue "strategic diversity goals" to improve firm's public image.

Table 3 shows the industry breakdown (based on 1-digit SIC codes) of the CEOs by gender and ethnicity. According to this panel, there is no clear difference in the way male vs. female CEOs, and Caucasian vs. minority CEOs are distributed across industries. In fact, correlation between the number of female vs. male CEOs in each industry is 0.90 , while the correlation for the number of Caucasian vs. minority CEOs in each industry is 0.86 . 
Table 4 shows the correlation matrix. There is a small but statistically significant positive correlation between the female dummy and the pay ratio (0.129). Consistent with Mueller et al. (2017), there is a positive relation between the pay ratio and firm size. There is a small negative correlation with B/M and PCI, and a positive correlation with ROA and Tobin's Q.

Table 5 presents the main results. In this table, CEO-to-employee pay ratio is regressed on the female and the minority dummies as well as other determinants of pay ratio found in prior literature. Results in Panel A show a positive and significant coefficient on the female dummy in all models (with $1 \%$ and $5 \%$ significance levels). This result supports the second hypothesis of the paper for females and suggests that females are paid a premium as a compensation either for superior quality or productivity, or because of the tight labor markets for female CEOs. Alternative explanation is that female CEOs pay lower salaries to their average employee which could be due to "the glass cliff" hypothesis, they are hired to turn around companies in precarious economic conditions. Panel B of Table 5 replicates results in Panel A, but clusters errors by firm. Although significance is reduced as expected, we still find a positive and significant coefficient on the female dummy.

The regression results further show that the coefficient on the minority dummy is negative (or near zero) and insignificant in all specifications. In Table 5, Panel C we include interaction of female and minority and find insignificant coefficient on that interaction as well.

Table 6 presents results with industry dummies. That is, the models in Table 5 are reanalyzed while controlling for the industry effects by including the Fama-French 48 industry dummies. The results stay robust and similar to the ones presented in Table 5. It should also be noted that, out of the 48 industries, the dummy for only one industry is significant in all specifications - the apparel industry. In the models with Fama-French industry dummies, the 
coefficients on the minority dummy are still insignificant, however they have a positive sign (in all specifications).

The results reveal that the firm size is positively associated with the CEO-to-employee pay ratio, consistent with results in Faleye et al. (2013) and Mueller et al. (2017). Also consistent with Faleye et al. (2013), the coefficient on the book-to-market ratio is negative and significant in most models.

For robustness, we conduct a matched sample analysis. Each female CEO in the sample is matched to a male CEO in the same 1-digit SIC code and Fama-French 48 industry group, with the closest firm size, measured as the fiscal-year-end market value of equity. A paired t-test for comparing the mean pay ratio of the two groups is carried out and the results are presented in Table 7 (see Panel A for the 1-digit SIC code match, and Panel B for Fama-French 48 industry group match results). This analysis shows that the difference is highly significant, with a pay ratio difference of 199.31 and a t-statistic of 2.73 for the 1-digit SIC code match. Results are still significant (even though, somewhat weaker) for the Fama-French 48 industry group match with a pay ratio difference of 146.49 and a t-statistic of 1.84 .

In Table 8, we demonstrate the results of additional analysis for the female subsample only. Panel A shows that white female CEOs have higher CEO-to-employee pay ratio (391.29) than minority female CEOs (207.96). This difference is statistically significant. In Table 8, Panel B we conduct multivariate analysis and find that minority female CEOs have lower CEO-to-employee pay ratio than white female CEOs. We find statistical significance in both univariate and multivariate analyses despite small sample size. 


\section{Discussion}

Motivated mainly by potential differences in values and management style of women and minority CEOs, or possible discrimination of female and minority executives, this paper examines whether companies headed by such executives have CEO-to-employee pay ratios that are substantially different from those headed by white male executives. While we expected the ratio to be smaller, there are a number of factors that may currently contribute to the opposite. Perhaps the most important factor is rapidly growing demand for diversity in executive positions in recent years, making the labor market for women and minority executives rather tight.

Examination of CEO-to-employee pay ratios has been limited to this date because information on compensation of an average employee at publicly traded companies was not available. The Dodd Frank Act mandated such disclosure, starting with the fiscal year 2017. Using this newly available data, this paper is able to obtain pay ratios for S\&P 1500 companies. By merging the data with ExecuComp and ISS databases, firms that are headed by females and minorities are identified for analysis.

The obtained results indicate that companies led by female CEOs have higher CEO-toemployee pay ratios in both univariate and multivariate analyses. The simple comparison of means revealed that companies headed by female CEOs have ratios that are $95 \%$ higher on average than those headed by male CEOs. The regression analysis, however, showed that the ratio for women is $22 \%$ (controlling for industry fixed effects) to $28 \%$ (without industry controls) higher than the comparison group of companies. That is, the conditional difference is between the ratios is substantially smaller, and can be explained by such factors as firm performance, size (including physical capital), duality of the CEO's role, and the CEO's on-the-job tenure.

We can offer several potential explanations to our results. Female CEOs are paid a premium for their superior performance or, alternatively, because current demand for female 
executives outstrips their supply, including due to the corporations fulfillment of "strategic diversity goals". The latter, in addition to regression results, finds support in the data that shows that women are overrepresented at the top end of the pay and ratio distributions, and only few female CEOs are hired by medium and smaller size firms in the S\&P1500 list. The data also shows that women CEOs are more likely to be hired by firms with lower employee pay, which provides support to the "glass cliff" explanation.

The "glass cliff" coupled with "differences in values" hypotheses find further support when we examine pay ratios of female CEOs by the minority status (univariate analysis). Female minority CEOs have lower pay ratios, higher employee pay (and slightly higher CEO compensation) than Caucasian, while having 3 more years of on-the-job tenure (8.5 versus 5.5 years). This suggests that they may be able to improve employee pay as they turn around their firms' economic fortunes, reducing the executive-employee pay gap. However, this evidence is relatively weak, including due to the very small number of minority female CEOs. Overall, other factors tilt the balance of forces determining the ratio, towards it being higher for women CEOs.

Our results do not show a significant difference in the CEO-to-employee pay ratio between minority CEOs and their Caucasian counterparts regardless of gender for the full sample. In multivariate analysis, coefficients on the minority CEO dummies are small and statistically insignificant, negative in the models without industry dummies, and positive in the models using Fama-French industry controls, suggesting that forces affecting the ratio cancel each other out. Our examination of the ratio histograms (similarly to female vs male) also showed that minority CEOs are less likely to be working in firms with low ratios than Caucasian CEOs, hinting that minority CEOs are also hired to fulfill "strategic diversity goals". However, they are underrepresented at the very top of the ratio distribution (and CEO pay), negating the effect of 
"demand for diversity". Our results for female CEOs broken down by minority status, showing lower ratios for minority female CEOs also corroborate this argument. This evidence suggests that the racial and ethnicity bias might still be a factor in determining CEO compensation.

Thus, our results indicate that, at the moment, CEO-to-median-employee pay ratios are positively affected by having a female $\mathrm{CEO}$, reflecting higher demand and, potentially, due to "the glass cliff" hiring. Having a female minority CEO is associated with lower CEO-to-employee ratio than for white female CEOs. While we acknowledge limitations of our inferences due to the short panel of data caused by the recency of the Dodd-Frank mandate, our findings shed new light onto interplay of gender, race and ethnicity in corporate compensation and overall inequality. By being the first to examine the pay ratios in this regard, we contribute to the existing academic discussion on CEO compensation, employee compensation, and inequality, as we outline a new path of research of combined CEO and employee pay and CEO diversity. 


\section{References}

Adams, S., Gupta, A., Haughton, D. and Leeth, J. (2007), "Gender differences in CEO compensation: evidence from the USA", Women in Management Review, Vol.22 No.3, pp. 208-224.

Balsam. S., Choi J.J. and Ju M. (2016), "What explains the CEO-worker pay ratios? Evidence on the effects of national culture and institutions around the world", working paper, Temple University, Philadelphia, July.

Balsam. S., Choi J.J., John K. and Ju M. (2019), "The impact of CEO ratio on firm value”, working paper, Temple University, Philadelphia, and New York University, New York.

Bardos, K.S., Kozlowski S. and Puleo, M. (2020), "Entrenchment or efficiency? CEO-to-employee pay ratio and the cost of debt", working paper, Fairfield University, Fairfield, February.

Barney, J.B. (1991), "Firm resources and sustained competitive advantage", Journal of Management, Vol.17 No.1, pp. 99-120.

Bertrand, M. and Hallock K. (2010), "The gender gap in top corporate jobs", Industrial and Labor Relations Review, Vol.55 No.1, pp. 3-21.

Blau, F. and DeVaro, J. (2007), "New Evidence on Gender Differences in Promotion Rates: An Empirical Analysis of a Sample of New Hires", Industrial Relations, Vol.46 No.3, pp. 511550 .

Blau F. and Kahn, L. (2017), “The gender wage gap: extent, trends, and explanations”, Journal of Economic Literature, Vol.55 No.3, pp. 789-865.

Bugeja M., Matolcsy Z. and Spiropoulos H. (2012), "Is there a gender gap in CEO compensation?", Journal of Corporate Finance, Vol.18 No.4, pp. 849-859.

Cardoso, A.R. and Winter-Ebmer, R. (2010), "Female-led firms and gender wage policies", ILR Review, Vol.64 No 1, pp. 143-163.

Cheng, Q., Ranasinghe, T. and Zhao, S. (2017), "Do high CEO pay ratios destroy firm value?", Research Collection School of Accountancy, Singapore Management University.

Cook, A. and Glass, C. (2014), "Analyzing promotions of racial/ethnic minority CEOs”, Journal of Managerial Psychology, Vol.29 No.4, pp. 440-454.

Cowherd, D.M. and Levine, D.I. (1992), "Product quality and pay equity between lower-level employees and top management: An investigation of distributive justice theory", Administrative Science Quarterly, pp. 302-320.

Crawford, S., Nelson, K.K. and Rountree, B. (2018), "Mind the gap: CEO-employee pay ratios and shareholder say on pay votes", working paper, University of Houston, Houston, Texas Christian University, Fort Worth, and Rice University, Houston, August 5. 
Cullen, Z. and Perez-Truglia, R. (2018), "How much does your boss make? The effects of salary comparisons”, NBER Working Paper \#24841.

Cullen, Z. and Pakzad-Hurson, B. (2019), "Equilibrium effects of pay transparency in a simple labor market", working paper, Harvard University, Boston and Brown University, Providence, May.

Dai, Y., Kong, D. and Xu, J. (2017), "Does fairness breed efficiency? Pay gap and firm productivity in China", International Review of Economics \& Finance, Vol.48, pp. 406-422.

Davis, J., Fama E. and French, K. (2000), "Characteristics, Covariances, and Average Returns: 1929 to 1997”, Journal of Finance, Vol.55 No.2, pp. 389-406.

Dittmann, I., Schneider, C. and Zhu, Y. (2018), "The additional costs of CEO compensation: the effect of relative wealth concerns of employees", European Corporate Governance Institute (ECGI) Finance Working Paper 559.

Dittmann, I., Montone, M. and Zhu, Y. (2018), "Wage gap and stock returns: do investors dislike pay Inequality?", working paper, Erasmus University Rotterdam, Netherlands and Utrecht University, Netherlands, October 1.

Elkin, H. (2016), “The interrelation between firm compensation system structure, equitable pay, and firm performance", Texas Tech University dissertation, Lubbock, May.

Faleye O., Reis E. and Venkateswaran A. (2013), "The determinants and effects of CEO-employee pay ratio”, Journal of Banking and Finance, Vol.37, pp. 3258-3272.

Falato, A., Milbourn, T. and Li, D. (2012), "CEO pay and the market for CEOs”, FEDS Working Paper No.2012-2039.

Feng, M., Wang, X. and Saini, J. (2015), "Monetary compensation, workforce-oriented corporate social responsibility, and firm performance", American Journal of Business, Vol.30 No.3, pp. 196-215.

Field, L.C., Souther, M.E., and Yore, A.S. (2019), "At the table but can not break through the glass ceiling: Board leadership positions elude diverse directors", Journal of Financial Economics, forthcoming.

Flabbi, L., Macis, M., Moro, A. and Schivardi, F. (2019), "Do female executives make a difference? The impact of female leadership on gender gaps and firm performance", The Economic Journal, Vol.129 No 622, pp. 2390-2423.

Gayle, G. L. and Golan, L. (2012), "Estimating a dynamic adverse-selection model: Labour-force experience and the changing gender earnings gap 1968-1997", Review of Economic Studies, Vol.79 No.1, pp. 227-267.

Geiler, P. and Renneboog, L. (2015), “Are female top managers really paid less?”, Journal of Corporate Finance, Vol.35, pp. 345-369. 
Glass, C. and Cook A. (2019), "Pathways to the glass cliff: a risk tax for women and minority leaders", Social Problems, 22 November 2019. https://doi.org/10.1093/socpro/spz045

Green, T.C. and Zhou, D. (2019), "Pay inequality, job satisfaction, and firm performance”, Baruch College Zicklin School of Business Research Paper No.2019-07-03.

Greenhaus, J.H. and Parasuraman, S. (1993), "Job performance attributions and career advancement prospects: An examination of gender and race effects," Organizational Behavior and Human Decision Processes, Vol.55 No.2, pp. 273-297.

Gu, Y. and Yang, Z. (2018), "Research on the relationship between external compensation gap of executives and enterprise innovation", Open Journal of Social Sciences, Vol.6 No.8, pp. 261-282.

Gupta, V., S. Mortal and Guo, X. (2018), "Revisiting the gender gap in CEO compensation: Replication and extension of Hill, Upadhyay, and Beekun's (2015) work on CEO gender pay gap", Strategic Management, Vol. 39. No. 7, pp. 2036-2050.

Haslam, S.A. and Ryan, M.K. (2008), "The road to the glass cliff: Differences in the perceived suitability of men and women for leadership positions in succeeding and failing organizations", The Leadership Quarterly, Vol.19 No.5, pp. 530-546.

Hill, A.D., Upadhyay, A. and Beekun, R.I. (2015), "Do female and ethnically diverse executives endure inequity in the CEO position or do they benefit from their minority status? An empirical examination”, Strategic Management Journal, Vol.36 No. 8, pp. 1115-1134.

Huang, G. Y., Huang, H. H. and Lee, C. I. (2019), "Is CEO pay disparity relevant to seasoned bondholders?", International Review of Economics and Finance, Vol. 64, pp. 271-289.

Huang, G.Y., Huang, H.H. and Yu, J. (2018), "CEO-employee pay ratio and bond yield spreads", Asian Finance Association 2018 conference.

Huang, Q., Jiang, F., Lie, E. and Que, T. (2017), "The Effect of Labor Unions on CEO Compensation", Journal of Financial and Quantitative Analysis, Vol.52 No.2, pp. 553-582.

Jalbert, T., Jalbert, M. and Furumo, K. (2013), “The relationship between CEO gender, financial performance, and financial management", Journal of Business and Economics Research, Vol.11 No.1, pp. 25-34.

Jiang, W., Lin, B., Liu, Y. and Xu, Y. (2019), "Chairperson collectivism and the compensation gap between managers and employees: evidence from China", Corporate Governance: An International Review, Vol.27 No.4, pp. 261-282.

Johnson, T. (2018), "Disclosure regulation and firm behavior: the effects of the mandated disclosure of CEO-to-Employee pay ratio on CEO pay", Florida State University dissertation. 
Joshi, A., Son, J. and Roh, H. (2015), "When can women close the gap? A meta-analytic test of sex differences in performance and rewards", Academy of Management Journal, Vol.58 No.5, pp. 1516-1545.

Jung, S.M., Kim, N.K.W., Ryu, H.S. and Shin, J.Y. (2018), "Why Do Firms Disclose a Supplementary CEO-to-Median Worker Pay Ratio? Initial Evidence from Dodd Frank Act Section 953 (b)", AAA 2019 Management Accounting Section (MAS) Meeting, August 18.

Kaplan, S.N., Klebanov, M.M. and Sorensen, M. (2012), "Which CEO characteristics and abilities matter?" The Journal of Finance, Vol.6 No.3, pp. 973-1007.

Keloharju, M., Knüpfer, S. and Tåg, J. (2016), "Equal opportunity? Gender gaps in CEO appointments and executive pay", Harvard Business School Working Paper, No.16-092, February.

Kiatpongsan S. and Norton, M. (2014), "How much (more) should CEOs make? A universal desire for more equal pay", Perspectives on Psychological Science, Vol.9 No.6, pp. 587-593.

Kini, O. and Williams, R. (2012), "Tournament incentives, firm risk and corporate policies", Journal of Financial Economics, Vol. 103, pp. 350-376.

Lei, L. (2017), “CEO-to-worker pay disparity and the cost of debt”, Virginia Polytechnic Institute dissertation.

Leslie, L. M., Manchester, C. and Dahm, P. (2017), "Why and when does the gender gap reverse? Diversity goals and the pay premium for high potential women", Academy of Management Journal, Vol.60 No.2, pp. 402-432.

Liu, Y. and Jiraporn, P. (2010), "The effect of CEO power on bond ratings and yields", Journal of Empirical Finance, Vol.17 No.4, pp. 744-762.

Magda I. and Cukrowska-Torzewska E. (2018), "Do female managers help to lower within-firm gender pay gaps? Public institutions vs. private enterprises", IZA DP No.12026, December 2018 .

Marisetty, V.B., Osano, H. and Venugopal, B. (2016), "Position, power and demand for CEOs: understanding executive compensation in the U.S market", 2nd Annual Financial Institutions, Regulation and Corporate Governance Conference, August 29.

Mishel, L. and Wolfe, J. (2019), "CEO compensation has grown 940\% since 1978”, Economic Policy Institute Report, August 14. https://www.epi.org/publication/ceo-compensation$\underline{2018 /}$

Mueller, H.M., Ouimet, P.P. and Simintzi, E. (2017), "Within-firm pay inequality", The Review of Financial Studies, Vol.30 No.10, pp. 3605-3635. 
Newton, D. and Simutin, M. (2015), "Of age, sex, and money: insights from corporate officer compensation on the wage inequality between genders", Management Science, Vol.61 No.10, pp. 2355-2375.

Okozi I., Smith K., Clark L. and Sherman, R. (2009), "MS leadership styles of ethnic minority leaders", American Psychological Association Communique, August. https://www.apa.org/pi/oema/resources/communique/2009/08/ethnic-leaders

Ryan, M. and Haslam, A. (2007), "The class cliff: exploring the dynamics surrounding the appointment of women to precarious leadership positions", Academy of Management Review, Vol.32 No.2, pp. 549-572.

Renner, C., Rives, J. and Bowlin W. (2002), "The significance of gender in explaining senior executive pay variations: an exploratory study", Journal of Managerial Issues, Vol.14 No.3, pp. 331-345.

Rouen, E. (2019), "Rethinking measurement of pay disparity and its relation to firm performance," The Accounting Review, forthcoming.

Rosen, S. (1981), "The economics of superstars", American Economic Review. Vol.71, pp. 845858.

Rosener, J. (1990), “Ways women lead”, Harvard Business Review, Vol.68 No.6, pp. 119-127.

Seung-Hwan, J. and Harrison, D.A. (2017), "Glass breaking, strategy making, and value creating: meta-analytic outcomes of women as CEOs and TMT members", Academy of Management Journal, Vol.60 No.4, pp. 1219-1252.

Shin, T. (2012), "The gender gap in executive compensation: the role of female directors and chief executive officers", The Annals of the American Academy of Political and Social Science, Vol.639 No.1, pp. 258-278.

Shin, J., Kang, S. Hyun, J. and Kim B. (2015), "Determinants and performance effects of executive pay multiples: Evidence from Korea”, Industrial and Labor Relations Review, Vol.68 No.1, pp. 53-78.

Smith N., Smith, V. and Verner, M. (2005), "Do women in top management affect firm performance? A Panel Study of 2500 Danish Firms", CIE Discussion Papers 2005-03, University of Copenhagen, Department of Economics, Centre for Industrial Economics.

Uygur, O. (2019), "Income inequality in S\&P 500 companies", The Quarterly Review of Economics and Finance, Vol.72 No.C, pp. 52-64.

Wolfers, J. (2006), "Diagnosing discrimination: stock returns and CEO gender", Journal of the European Economic Association, Vol.4 No.(2-3), pp. 531-541.

Xu, M., Kong, G. and Kong, D. (2017), "Does wage justice hamper creativity? Pay gap and firm innovation in China", China Economic Review, Vol.44, pp. 186-202. 
Zhao, Q. and Wang, Y. (2019), "Pay gap, inventor promotion and corporate technology innovation", China Finance Review International, Vol.9 No.2, pp. 154-182.

Zweigenhaft, R. and Domhoff, G.W. (2010), “The new CEOs: women, African American, Latino, and Asian American leaders of Fortune 500 companies", Rowman \& Littelfield Publishers, Inc. 


\section{Figure 1: Histogram of Pay Ratio by Gender}

This figure presents the histogram for the log of Pay Ratio for firms with Male vs. Female CEOs, showing the fraction of firms in each of the 50 Pay Ratio bins within Male and Female CEO groups.

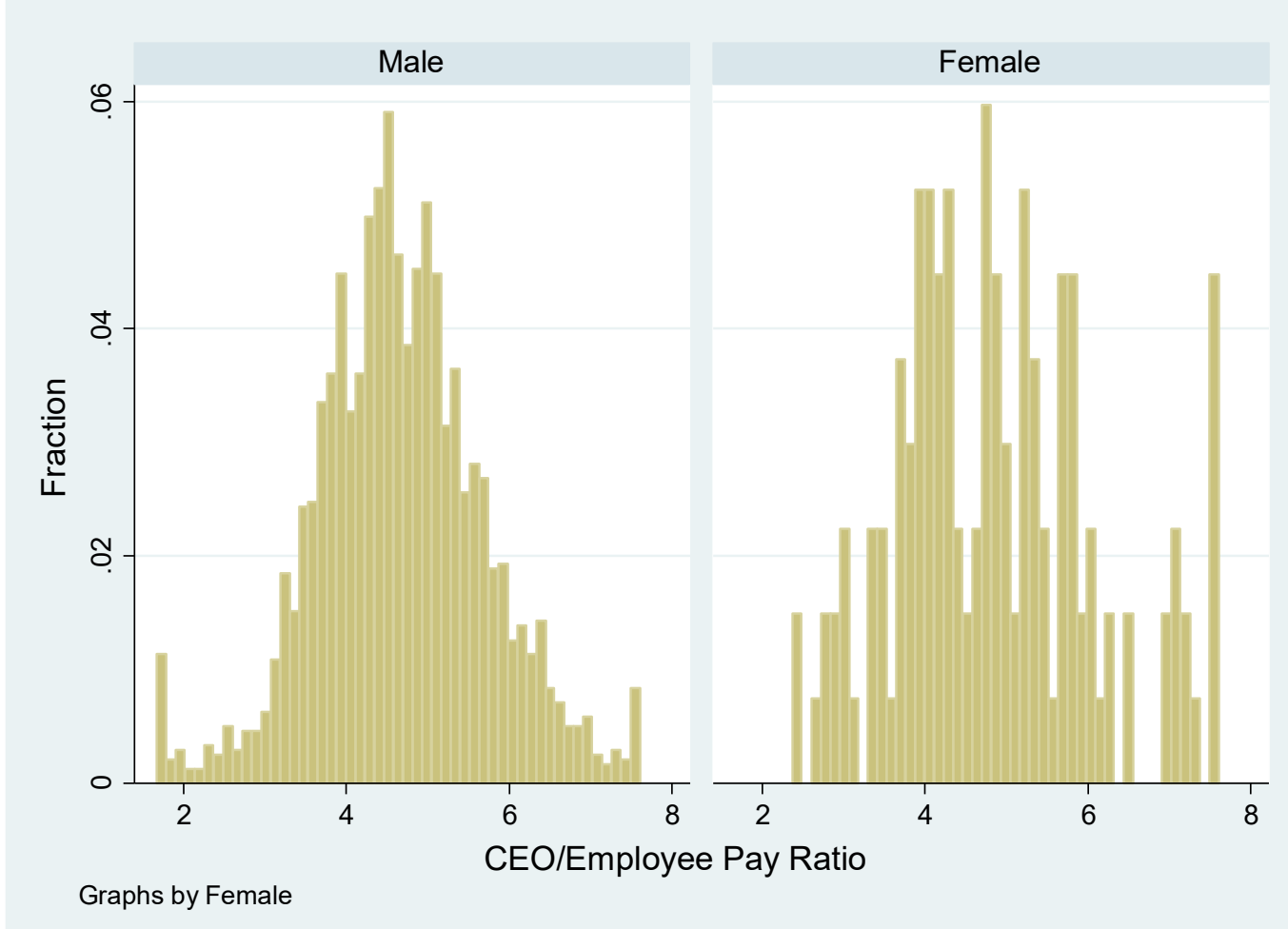




\section{Table 1: Variable Definitions}

This table presents a list of the variables used in the analyses and provides their definitions along with the database they are obtained from. MyLogIQ is a database constructed by collecting CEO and median employee pays from Schedule 14A. ExecuComp provides data on executive compensation and CEO characteristics. ISS is Institutional Shareholder Services. CCM is the CRSP/Compustat Merged database.

\begin{tabular}{|c|c|c|}
\hline Source & Variable Name & Variable Description \\
\hline MyLogIQ & CEO Comp & CEO Total Compensation \\
\hline MyLogIQ & Employee Comp & Median Employee's Compensation \\
\hline MyLogIQ & Pay Ratio & Natural log of CEO Compensation divided by Median Employee Compensation \\
\hline ExecuComp & Female & Dummy variable that equals 1 if the CEO is female; 0 otherwise \\
\hline ExecuComp & Duality & Dummy variable that equals 1 if the CEO is also serving as the Chairman of the Board; 0 otherwise \\
\hline ExecuComp & Tenure & Number of years since the current CEO took office \\
\hline ISS & Minority & Dummy variable that equals 0 if the CEO's ethnicity is Caucasian; 1 otherwise \\
\hline $\mathrm{CCM}$ & Size & Firm size measured as natural log of firm's total assets (AT) \\
\hline $\mathrm{CCM}$ & $\mathrm{B} / \mathrm{M}$ & Book-to-Market: Book value of equity divided by market value of equity (CSHO*PRCC_F) \\
\hline $\mathrm{CCM}$ & $\mathrm{ROA}$ & Return on Assets: Ratio of income before extraordinary items (IB) divided by prior year total assets (AT) \\
\hline $\mathrm{CCM}$ & Tobin's Q & $\begin{array}{l}\text { Market value of equity }(\mathrm{CSHO} * \mathrm{PRCC} F \text { ) plus book value of liabilities (LT) plus preferred equity } \\
\text { redemption value (PSTKRV), divided by total assets (AT) }\end{array}$ \\
\hline $\mathrm{CCM}$ & PCI & Physical Capital Intensity: Net PPE (PPENT) divided by number of employees (EMP) \\
\hline
\end{tabular}




\section{Table 2: Summary Statistics}

This table presents summary statistics for the variables. See Table 1 for variable definitions. CEO Comp and Employee Comp are in actual dollars. PCI is in million dollars. Panel A reports summary statistics for compensation variables and the Pay Ratio for the full sample. Panel B reports means for all variables separately for firms with a Female vs. Male CEO; and for firms with a Minority vs. Caucasian CEO. Columns titled "All" present the means for the subsample where Gender or Ethnicity variable is available. Panel $\mathrm{C}$ reports the means for all variables for Caucasian vs. Minority CEOs within Female and Male subsamples. Panel D reports the mean comparison t-test results comparing the Pay Ratio for Male vs. Female and Caucasian vs. Minority groups in the full sample, as well as Caucasian, Minority, Female, and Male subsamples. Panel E reports the mean comparison t-test results comparing CEO and median employee compensations within Female, Minority, Male, and Caucasian subsamples. In Panels D and E, t-stats are calculated assuming both equal and unequal variances for the comparison samples, and *,**,*** stars indicate significance at 10\%,5\%, and 1\% levels using the one-tailed t-test benchmarks. The sample includes 2017 and 2018 fiscal years for S\&P 1500 firms.

Panel A: Compensation Variables

\begin{tabular}{lccccccc}
\hline & N & 1st Pctl & 25th Pctl & Mean & Median & 75th Pctl & 99th Pctl \\
\hline CEO Comp (\$) & 2,520 & 357,760 & $3,695,132$ & $8,544,852$ & $6,354,683$ & $11,100,000$ & $35,700,000$ \\
Employee Comp (\$) & 2,520 & 5,501 & 42,078 & 71,263 & 62,014 & 91,710 & 223,882 \\
Pay Ratio (actual) & 2,520 & 5.50 & 53.76 & 201.65 & 102.04 & 201.82 & 1794.56 \\
Pay Ratio (log) & 2,515 & 1.89 & 3.99 & 4.66 & 4.63 & 5.31 & 7.49 \\
\hline
\end{tabular}

Panel B: All Variables by Gender and Ethnicity

\begin{tabular}{lcccccc}
\hline & Female & Male & All & Minority & Caucasian & All \\
\hline No of Observations & 134 & 2,386 & 2,520 & 135 & 1,775 & 1,910 \\
CEO Comp (\$) & $9,986,338$ & $8,463,897$ & $8,544,852$ & $8,533,950$ & $8,500,363$ & $8,502,737$ \\
Employee Comp (\$) & 68,184 & 71,436 & 71,263 & 75,216 & 70,177 & 70,534 \\
Pay Ratio (actual) & 373.88 & 191.98 & 201.65 & 172.74 & 203.37 & 201.21 \\
Female & 1.00 & 0.00 & 0.05 & 0.06 & 0.05 & 0.06 \\
Minority & 0.08 & 0.07 & 0.07 & 1.00 & 0.00 & 0.07 \\
Duality & 0.33 & 0.42 & 0.42 & 0.39 & 0.41 & 0.41 \\
Tenure & 5.45 & 8.47 & 8.31 & 9.92 & 8.79 & 8.87 \\
Size & 8.60 & 8.54 & 8.54 & 8.37 & 8.59 & 8.58 \\
B/M & 0.47 & 0.55 & 0.55 & 0.39 & 0.55 & 0.54 \\
ROA & 0.06 & 0.05 & 0.05 & 0.06 & 0.05 & 0.05 \\
Tobin's Q & 2.03 & 2.06 & 2.05 & 2.75 & 2.01 & 2.06 \\
PCI (\$mil) & 0.44 & 0.57 & 0.56 & 0.18 & 0.55 & 0.52 \\
\hline
\end{tabular}


Panel C: Summary Statistics by Caucasian vs Minority for Female and Male CEOs

\begin{tabular}{|c|c|c|c|c|c|c|}
\hline & \multicolumn{3}{|c|}{ Female Subsample } & \multicolumn{3}{|c|}{ Male Subsample } \\
\hline & Caucasian & Minority & All & Caucasian & Minority & All \\
\hline No of Observations & 97 & 8 & 105 & 1,667 & 127 & 1,794 \\
\hline CEO Comp (\$) & $10,700,000$ & $12,500,000$ & $10,800,000$ & $8,372,246$ & $8,283,819$ & $8,365,987$ \\
\hline Employee Comp (\$) & 66,743 & 84,429 & 68,091 & 70,420 & 74,636 & 70,719 \\
\hline Pay Ratio (actual) & 391.29 & 207.96 & 377.33 & 192.90 & 170.52 & 191.32 \\
\hline Female & 1.00 & 1.00 & 1.00 & 0.00 & 0.00 & 0.00 \\
\hline Minority & 0.00 & 1.00 & 0.08 & 0.00 & 1.00 & 0.07 \\
\hline Duality & 0.36 & 0.25 & 0.35 & 0.42 & 0.40 & 0.42 \\
\hline Tenure & 5.55 & 8.55 & 5.78 & 8.98 & 10.00 & 9.06 \\
\hline Size & 8.68 & 9.34 & 8.73 & 8.59 & 8.31 & 8.57 \\
\hline $\mathrm{B} / \mathrm{M}$ & 0.47 & 0.29 & 0.45 & 0.55 & 0.40 & 0.54 \\
\hline ROA & 0.07 & 0.06 & 0.06 & 0.05 & 0.06 & 0.05 \\
\hline Tobin's Q & 2.00 & 2.88 & 2.07 & 2.01 & 2.74 & 2.06 \\
\hline PCI (\$mil) & 0.39 & 0.33 & 0.38 & 0.56 & 0.17 & 0.53 \\
\hline
\end{tabular}


Panel D: Mean Comparison Tests for Pay Ratio

\begin{tabular}{|c|c|c|c|c|}
\hline & \multicolumn{2}{|c|}{ Full Sample } & \multirow[b]{2}{*}{ t-stat } & \multirow[b]{2}{*}{ t-stat (uneq $\left.\sigma^{2}\right)$} \\
\hline & Male & Female & & \\
\hline $\mathrm{N}$ & 2386 & 134 & & \\
\hline Mean & 191.98 & 373.88 & $-5.74 * * *$ & $-2.51 * * *$ \\
\hline \multirow[t]{2}{*}{ St Dev } & 309.00 & 837.38 & & \\
\hline & White & Minority & t-stat & t-stat (uneq $\sigma^{2}$ ) \\
\hline $\mathrm{N}$ & 1775 & 135 & & \\
\hline Mean & 203.37 & 172.74 & 0.98 & $1.58 *$ \\
\hline \multirow[t]{3}{*}{ St Dev } & 359.00 & 202.86 & & \\
\hline & \multicolumn{2}{|c|}{ Caucasian Subsample } & & \\
\hline & Male & Female & t-stat & t-stat (uneq $\sigma^{2}$ ) \\
\hline $\mathrm{N}$ & 1667 & 97 & & \\
\hline Mean & 192.90 & 391.29 & $-5.32 * * *$ & $-2.49 * * *$ \\
\hline \multirow[t]{3}{*}{ St Dev } & 315.95 & 781.20 & & \\
\hline & \multicolumn{2}{|c|}{ Minority Subsample } & & \\
\hline & Male & Female & t-stat & t-stat (uneq $\sigma^{2}$ ) \\
\hline $\mathrm{N}$ & 127 & 8 & & \\
\hline Mean & 170.52 & 207.96 & -0.50 & -0.42 \\
\hline \multirow[t]{3}{*}{ St Dev } & 200.77 & 246.35 & & \\
\hline & \multicolumn{2}{|c|}{ Female Subsample } & & \\
\hline & Caucasian & Minority & t-stat & t-stat (uneq $\sigma^{2}$ ) \\
\hline $\mathrm{N}$ & 97 & 8 & & \\
\hline Mean & 391.29 & 207.96 & 0.66 & $1.56^{*}$ \\
\hline \multirow[t]{3}{*}{ St Dev } & 781.20 & 246.35 & & \\
\hline & \multicolumn{2}{|c|}{ Male Subsample } & & \\
\hline & Caucasian & Minority & t-stat & t-stat (uneq $\sigma^{2}$ ) \\
\hline $\mathrm{N}$ & 1667 & 127 & & \\
\hline Mean & 192.90 & 170.52 & 0.79 & 1.15 \\
\hline St Dev & 315.95 & 200.77 & & \\
\hline
\end{tabular}


Panel E: Mean Comparison Tests for CEO and Median Employee Compensation

\begin{tabular}{|c|c|c|c|c|c|}
\hline & \multicolumn{3}{|c|}{ Female Subsample } & \multirow[b]{2}{*}{ t-stat } & \multirow[b]{2}{*}{ t-stat (uneq $\left.\sigma^{2}\right)$} \\
\hline & Caucasian & Minority & All & & \\
\hline No of Observations & 97 & 8 & 105 & & \\
\hline CEO Comp (\$) & $10,700,000$ & $12,500,000$ & $10,800,000$ & -0.40 & -0.47 \\
\hline Employee Comp (\$) & 66,743 & 84,429 & 68,091 & -1.10 & -1.38 \\
\hline $\operatorname{Ln}($ CEO Comp $)$ & 15.83 & 15.96 & 15.84 & -0.43 & -0.36 \\
\hline \multirow[t]{3}{*}{ Ln(Employee Comp) } & 10.81 & 11.27 & 10.85 & $-1.41^{*}$ & $-2.62 * *$ \\
\hline & \multicolumn{3}{|c|}{ Minority Subsample } & & \\
\hline & Male & Female & All & t-stat & t-stat (uneq $\sigma^{2}$ ) \\
\hline No of Observations & 127 & 8 & 135 & & \\
\hline CEO Comp (\$) & $8,283,819$ & $12,500,000$ & $8,533,950$ & $-1.69 * *$ & -1.15 \\
\hline Employee Comp (\$) & 74,636 & 84,429 & 75,216 & -0.64 & -0.78 \\
\hline Ln(CEO Comp) & 15.64 & 15.96 & 15.66 & -1.09 & -0.84 \\
\hline \multirow[t]{3}{*}{ Ln(Employee Comp) } & 11.00 & 11.27 & 11.02 & -1.01 & $-1.65^{*}$ \\
\hline & \multicolumn{3}{|c|}{ Male Subsample } & & \\
\hline & Caucasian & Minority & All & t-stat & t-stat (uneq $\sigma^{2}$ ) \\
\hline No of Observations & 1,667 & 127 & 1,794 & & \\
\hline CEO Comp (\$) & $8,372,246$ & $8,283,819$ & $8,365,987$ & 0.10 & 0.14 \\
\hline Employee Comp (\$) & 70,420 & 74,636 & 70,719 & -1.03 & -1.08 \\
\hline Ln(CEO Comp) & 15.59 & 15.64 & 15.59 & -0.59 & -0.76 \\
\hline \multirow[t]{3}{*}{ Ln(Employee Comp) } & 10.94 & 11.00 & 10.94 & -0.97 & -0.98 \\
\hline & \multicolumn{3}{|c|}{ Caucasian Subsample } & & \\
\hline & Male & Female & All & t-stat & t-stat (uneq $\sigma^{2}$ ) \\
\hline No of Observations & 1,667 & 97 & 1,764 & & \\
\hline CEO Comp (\$) & $8,372,246$ & $10,700,000$ & $8,500,030$ & $-2.33 * * *$ & $-1.83 * *$ \\
\hline Employee Comp (\$) & 70,420 & 66,743 & 70,218 & 0.79 & 0.79 \\
\hline Ln(CEO Comp) & 15.59 & 15.83 & 15.60 & $-2.17 * *$ & $-2.62 * * *$ \\
\hline Ln(Employee Comp) & 10.94 & 10.81 & 10.93 & $1.52 *$ & $1.30^{*}$ \\
\hline
\end{tabular}




\section{Table 3: Distribution of CEOs by Gender \& Ethnicity across Industries}

This table reports the number of Female vs. Male, and Minority vs. Caucasian CEOs across the ten industries defined by the firms' 1-digit SIC codes. The sample includes 2017 and 2018 fiscal years for S\&P 1500 firms.

\begin{tabular}{ccccccc}
\hline SIC Code & Female & Male & Total & Minority & Caucasian & Total \\
\hline 0 & 0 & 1 & 1 & 0 & 1 & 1 \\
1 & 2 & 151 & 153 & 1 & 112 & 113 \\
2 & 22 & 352 & 374 & 20 & 243 & 263 \\
3 & 31 & 532 & 563 & 39 & 391 & 430 \\
4 & 20 & 214 & 234 & 14 & 155 & 169 \\
5 & 19 & 238 & 257 & 6 & 188 & 194 \\
6 & 24 & 565 & 589 & 26 & 443 & 469 \\
7 & 10 & 251 & 261 & 26 & 176 & 202 \\
8 & 6 & 76 & 82 & 3 & 62 & 65 \\
9 & 0 & 6 & 6 & 0 & 4 & 4 \\
\hline Total & 134 & 2,386 & 2,520 & 135 & 1,775 & 1,910 \\
\hline
\end{tabular}




\section{Table 4: Correlations}

This table presents the pairwise Spearman correlation between the variables. See Table 1 for variable descriptions. The sample includes 2017 and 2018 fiscal years for S\&P 1500 firms. *, **, *** stars indicate significance at 10\%, 5\%, and 1\% levels.

\begin{tabular}{|c|c|c|c|c|c|c|c|c|c|c|c|c|c|}
\hline & & {$[1]$} & [2] & [3] & [4] & [5] & {$[6]$} & [7] & [8] & [9] & [10] & [11] & [12] \\
\hline CEO Comp & {$[1]$} & 1.000 & & & & & & & & & & & \\
\hline Emp Comp & {$[2]$} & $0.140 * * *$ & 1.000 & & & & & & & & & & \\
\hline Pay Ratio & {$[3]$} & $0.400 * * *$ & $-0.371 * * *$ & 1.000 & & & & & & & & & \\
\hline LN(Pay Ratio) & {$[4]$} & $0.422 * * *$ & $-0.468 * * *$ & $0.614 * * *$ & 1.000 & & & & & & & & \\
\hline Female & {$[5]$} & $0.058 * *$ & -0.020 & $0.129 * * *$ & $0.067 * * *$ & 1.000 & & & & & & & \\
\hline Duality & {$[6]$} & $0.097 * * *$ & 0.025 & 0.011 & $0.063 * * *$ & -0.037 & 1.000 & & & & & & \\
\hline Tenure & {$[7]$} & 0.000 & 0.006 & $-0.045^{*}$ & $-0.077 * * *$ & $-0.103 * * *$ & $0.403 * * *$ & 1.000 & & & & & \\
\hline Minority & {$[8]$} & -0.008 & $0.041^{*}$ & -0.027 & -0.013 & 0.007 & -0.015 & $0.044 *$ & 1.000 & & & & \\
\hline Size & [9] & $0.389 * * *$ & $0.186^{* * *}$ & $0.097 * * *$ & $0.227 * * *$ & 0.021 & $0.169 * * *$ & $-0.082 * * *$ & -0.038 & 1.000 & & & \\
\hline $\mathrm{B} / \mathrm{M}$ & {$[10]$} & $-0.071 * * *$ & $0.046 *$ & $-0.068 * * *$ & $-0.069 * * *$ & -0.031 & -0.032 & -0.035 & $-0.067 * * *$ & $0.082 * * *$ & 1.000 & & \\
\hline $\mathrm{ROA}$ & [11] & $0.049 * *$ & 0.003 & 0.036 & $0.060 * *$ & 0.030 & 0.024 & $0.042 *$ & 0.027 & $-0.071 * * *$ & $-0.247 * * *$ & 1.000 & \\
\hline Tobin's Q & {$[12]$} & $0.054 * *$ & $0.062 * * *$ & $0.040^{*}$ & 0.016 & 0.001 & 0.017 & $0.083 * * *$ & $0.117 * * *$ & $-0.247 * * *$ & $-0.372 * * *$ & $0.472 * * *$ & 1.000 \\
\hline PCI & [13] & 0.008 & $0.357 * * *$ & $-0.059 * *$ & $-0.093 * * *$ & -0.011 & -0.009 & -0.013 & -0.032 & $0.070 * * *$ & $0.086 * * *$ & -0.033 & $-0.058 * *$ \\
\hline
\end{tabular}




\section{Table 5: Regression Analysis: Determinants of Pay Ratio}

This table presents the regression results where the dependent variable is the natural log of the Pay Ratio. The explanatory variables are described in Table 1. All specifications include a 2018 fiscal year dummy, but do not include industry dummies. Panel A presents the base model with panel regressions. Panel B presents the panel regression results where standard errors are clustered by firm. Panel C also presents panel regressions with standard errors clustered by firm, using the Female*Minority interaction dummy instead of the Minority dummy in the explanatory variables. The sample includes 2017 and 2018 fiscal years for S\&P 1500 firms. T-stats are given in brackets, and $*, * *, * * *$ stars indicate significance at $10 \%, 5 \%$, and $1 \%$ levels.

Panel A: Base Model

\begin{tabular}{|c|c|c|c|c|c|c|c|c|c|c|}
\hline 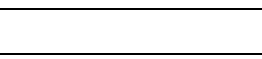 & Model 1 & Model 2 & Model 3 & Model 4 & Model 5 & Model 6 & Model 7 & Model 8 & Model 9 & Model 10 \\
\hline \multirow{2}{*}{ Female } & $0.25^{* *}$ & & $0.34 * * *$ & $0.31 * * *$ & $0.30 * *$ & $0.29 * *$ & $0.29 * *$ & $0.31 * *$ & $0.31 * *$ & $0.28 * *$ \\
\hline & {$[2.24]$} & & [2.73] & [2.58] & {$[2.46]$} & [2.39] & {$[2.45]$} & {$[2.46]$} & {$[2.51]$} & {$[2.23]$} \\
\hline \multirow[t]{2}{*}{ Minority } & & -0.03 & -0.03 & 0.01 & 0 & -0.02 & -0.03 & -0.08 & -0.08 & -0.06 \\
\hline & & {$[-0.24]$} & {$[-0.26]$} & {$[0.09]$} & {$[-0.00]$} & {$[-0.19]$} & {$[-0.33]$} & {$[-0.71]$} & {$[-0.69]$} & {$[-0.55]$} \\
\hline \multirow[t]{2}{*}{ Size } & & & & $0.17 * * *$ & $0.17 * * *$ & $0.18 * * *$ & $0.18 * * *$ & $0.18 * * *$ & $0.18 * * *$ & $0.17 * * *$ \\
\hline & & & & {$[10.23]$} & {$[10.51]$} & [10.76] & [10.94] & {$[10.36]$} & {$[10.01]$} & {$[9.54]$} \\
\hline \multirow[t]{2}{*}{ ROA } & & & & & $1.15 * * *$ & $0.88 * * *$ & 0.6 & 0.57 & 0.57 & 0.58 \\
\hline & & & & & [3.57] & {$[2.65]$} & [1.64] & {$[1.54]$} & {$[1.52]$} & {$[1.56]$} \\
\hline \multirow[t]{2}{*}{$\mathrm{B} / \mathrm{M}$} & & & & & & $-0.15 * * *$ & $-0.12 * * *$ & $-0.11 * *$ & $-0.11 * *$ & $-0.11^{* *}$ \\
\hline & & & & & & {$[-3.30]$} & {$[-2.62]$} & {$[-2.31]$} & {$[-2.28]$} & {$[-2.29]$} \\
\hline \multirow[t]{2}{*}{ Tobin's Q } & & & & & & & $0.04 *$ & 0.02 & 0.02 & 0.03 \\
\hline & & & & & & & [1.73] & [1.11] & [1.07] & [1.23] \\
\hline \multirow[t]{2}{*}{ PCI } & & & & & & & & $-0.04 * * *$ & $-0.04 * * *$ & $-0.04 * * *$ \\
\hline & & & & & & & & [-4.46] & [-4.44] & [-4.43] \\
\hline \multirow[t]{2}{*}{ Duality } & & & & & & & & & 0.06 & $0.14 * *$ \\
\hline & & & & & & & & & [1.09] & [2.14] \\
\hline \multirow[t]{2}{*}{ Tenure } & & & & & & & & & & $-0.01 * * *$ \\
\hline & & & & & & & & & & {$[-3.19]$} \\
\hline \multirow[t]{2}{*}{ Fiscal Yr-2018 } & 0.05 & 0.05 & 0.05 & 0.06 & 0.05 & 0.06 & 0.06 & 0.07 & 0.08 & 0.07 \\
\hline & {$[1.03]$} & {$[0.92]$} & [0.89] & {$[1.07]$} & {$[0.83]$} & {$[1.05]$} & {$[1.07]$} & {$[1.25]$} & {$[1.31]$} & {$[1.30]$} \\
\hline \multirow[t]{2}{*}{ Intercept } & $4.62 * * *$ & $4.64 * * *$ & $4.63 * * *$ & $3.19 * * *$ & $3.10 * * *$ & $3.15 * * *$ & $3.01 * * *$ & $3.11 * * *$ & $3.11 * * *$ & $3.24 * * *$ \\
\hline & [125.14] & [113.17] & [110.92] & [21.80] & [20.88] & [21.17] & [18.11] & [17.98] & [17.98] & [18.17] \\
\hline $\begin{array}{l}\text { Industry } \\
\text { Dummies }\end{array}$ & No & No & No & No & No & No & No & No & No & No \\
\hline R-sq & 0.002 & -0.001 & 0.003 & 0.055 & 0.06 & 0.065 & 0.067 & 0.072 & 0.072 & 0.078 \\
\hline $\mathrm{N}$ & 2,515 & 1,906 & 1,895 & 1,895 & 1,894 & 1,894 & 1,890 & 1,757 & 1,756 & 1,747 \\
\hline
\end{tabular}


Panel B: Base Model with Standard Errors Clustered by Firm

\begin{tabular}{|c|c|c|c|c|c|c|c|c|c|c|}
\hline & Model 1 & Model 2 & Model 3 & Model 4 & Model 5 & Model 6 & Model 7 & Model 8 & Model 9 & Model 10 \\
\hline \multirow[t]{2}{*}{ Female } & $0.25 *$ & & $0.34 * *$ & $0.31 * *$ & $0.30 *$ & $0.29 *$ & $0.29 *$ & $0.31 *$ & $0.31 * *$ & $0.28 *$ \\
\hline & [1.66] & & {$[2.11]$} & {$[1.98]$} & {$[1.90]$} & [1.84] & [1.89] & [1.95] & [1.98] & {$[1.75]$} \\
\hline \multirow[t]{2}{*}{ Minority } & & -0.03 & -0.03 & 0.01 & 0.00 & -0.02 & -0.03 & -0.08 & -0.08 & -0.06 \\
\hline & & {$[-0.23]$} & {$[-0.24]$} & [0.09] & {$[-0.00]$} & {$[-0.18]$} & {$[-0.31]$} & {$[-0.67]$} & {$[-0.66]$} & {$[-0.52]$} \\
\hline \multirow[t]{2}{*}{ Size } & & & & $0.17 * * *$ & $0.17 * * *$ & $0.18 * * *$ & $0.18 * * *$ & $0.18 * * *$ & $0.18 * * *$ & $0.17 * * *$ \\
\hline & & & & {$[5.47]$} & [5.49] & {$[5.54]$} & {$[5.27]$} & [4.89] & {$[4.41]$} & {$[4.23]$} \\
\hline \multirow[t]{2}{*}{ ROA } & & & & & $1.15^{* *}$ & $0.88 * *$ & 0.60 & 0.57 & 0.57 & 0.58 \\
\hline & & & & & {$[2.48]$} & {$[2.01]$} & {$[1.53]$} & {$[1.46]$} & [1.44] & [1.49] \\
\hline \multirow[t]{2}{*}{$\mathrm{B} / \mathrm{M}$} & & & & & & $-0.15 * * *$ & $-0.12 * * *$ & $-0.11 * *$ & $-0.11 * *$ & $-0.11 * *$ \\
\hline & & & & & & {$[-2.81]$} & {$[-2.64]$} & {$[-2.53]$} & {$[-2.53]$} & {$[-2.52]$} \\
\hline \multirow[t]{2}{*}{ Tobin's Q } & & & & & & & 0.04 & 0.02 & 0.02 & 0.03 \\
\hline & & & & & & & [1.37] & {$[0.88]$} & {$[0.83]$} & {$[0.96]$} \\
\hline \multirow[t]{2}{*}{ PCI } & & & & & & & & $-0.04 * * *$ & $-0.04 * * *$ & $-0.04 * * *$ \\
\hline & & & & & & & & {$[-2.82]$} & {$[-2.81]$} & {$[-2.74]$} \\
\hline \multirow[t]{2}{*}{ Duality } & & & & & & & & & 0.06 & 0.14 \\
\hline & & & & & & & & & {$[0.71]$} & [1.49] \\
\hline \multirow[t]{2}{*}{ Tenure } & & & & & & & & & & $-0.01 * *$ \\
\hline & & & & & & & & & & {$[-2.23]$} \\
\hline \multirow[t]{2}{*}{ Fiscal Yr-2018 } & $0.05 * *$ & $0.05 *$ & $0.05 *$ & $0.06^{* *}$ & $0.05^{*}$ & $0.06 * *$ & $0.06^{* *}$ & $0.07 * * *$ & $0.08 * * *$ & $0.07 * * *$ \\
\hline & [2.15] & [1.95] & [1.87] & [2.29] & {$[1.76]$} & [2.19] & {$[2.25]$} & {$[2.67]$} & [2.82] & {$[2.79]$} \\
\hline \multirow[t]{2}{*}{ Intercept } & $4.62 * * *$ & $4.64 * * *$ & $4.63 * * *$ & $3.19 * * *$ & $3.10 * * *$ & $3.15 * * *$ & $3.01 * * *$ & $3.11 * * *$ & $3.11 * * *$ & $3.24 * * *$ \\
\hline & [128.79] & [110.49] & [107.94] & {$[12.52]$} & [11.48] & [11.83] & [9.24] & [9.03] & [9.00] & [9.24] \\
\hline $\begin{array}{l}\text { Industry } \\
\text { Dummies }\end{array}$ & No & No & No & No & No & No & No & No & No & No \\
\hline R-sq & 0.002 & -0.001 & 0.003 & 0.055 & 0.06 & 0.065 & 0.067 & 0.072 & 0.072 & 0.078 \\
\hline $\mathrm{N}$ & 2,515 & 1,906 & 1,895 & 1,895 & 1,894 & 1,894 & 1,890 & 1,757 & 1,756 & 1,747 \\
\hline
\end{tabular}


Panel C: Female and Minority Interaction with Standard Errors are Clustered by Firm

\begin{tabular}{|c|c|c|c|c|c|c|c|c|c|}
\hline & Model 1 & Model 2 & Model 3 & Model 4 & Model 5 & Model 6 & Model 7 & Model 8 & Model 9 \\
\hline \multirow[t]{2}{*}{ Female } & $0.25 *$ & $0.36 * *$ & $0.34 * *$ & $0.33 * *$ & $0.32 * *$ & $0.33 * *$ & $0.35 * *$ & $0.36 * *$ & $0.32 *$ \\
\hline & {$[1.66]$} & {$[2.16]$} & {$[2.09]$} & {$[2.01]$} & {$[1.96]$} & {$[2.04]$} & {$[2.12]$} & {$[2.14]$} & {$[1.89]$} \\
\hline \multirow[t]{2}{*}{ Female*Minority } & & -0.32 & -0.43 & -0.43 & -0.46 & -0.49 & -0.54 & -0.53 & -0.48 \\
\hline & & {$[-0.58]$} & {$[-0.88]$} & {$[-0.92]$} & {$[-1.01]$} & [-1.09] & {$[-1.20]$} & [-1.19] & [-1.09] \\
\hline \multirow[t]{2}{*}{ Size } & & & $0.17 * * *$ & $0.17 * * *$ & $0.18 * * *$ & $0.18 * * *$ & $0.18 * * *$ & $0.18 * * *$ & $0.17 * * *$ \\
\hline & & & {$[5.48]$} & [5.49] & [5.54] & {$[5.28]$} & [4.90] & [4.42] & [4.24] \\
\hline \multirow[t]{2}{*}{ ROA } & & & & $1.15^{* *}$ & $0.88 * *$ & 0.60 & 0.57 & 0.57 & 0.58 \\
\hline & & & & [2.49] & {$[2.00]$} & [1.52] & [1.45] & [1.44] & [1.49] \\
\hline \multirow[t]{2}{*}{$\mathrm{B} / \mathrm{M}$} & & & & & $-0.15 * * *$ & $-0.12 * * *$ & $-0.11 * *$ & $-0.11 * *$ & $-0.11 * *$ \\
\hline & & & & & {$[-2.83]$} & {$[-2.64]$} & {$[-2.53]$} & {$[-2.52]$} & {$[-2.52]$} \\
\hline \multirow[t]{2}{*}{ Tobin's Q } & & & & & & 0.04 & 0.02 & 0.02 & 0.03 \\
\hline & & & & & & {$[1.41]$} & {$[0.88]$} & {$[0.83]$} & {$[0.96]$} \\
\hline \multirow[t]{2}{*}{ PCI } & & & & & & & $-0.04 * * *$ & $-0.04 * * *$ & $-0.04 * * *$ \\
\hline & & & & & & & {$[-2.83]$} & {$[-2.81]$} & {$[-2.74]$} \\
\hline \multirow[t]{2}{*}{ Duality } & & & & & & & & 0.06 & 0.14 \\
\hline & & & & & & & & {$[0.70]$} & [1.47] \\
\hline \multirow[t]{2}{*}{ Tenure } & & & & & & & & & $-0.01 * *$ \\
\hline & & & & & & & & & {$[-2.21]$} \\
\hline \multirow[t]{2}{*}{ Fiscal Yr-2018 } & $0.05 * *$ & $0.05^{*}$ & $0.06 * *$ & $0.05^{*}$ & $0.06 * *$ & $0.06 * *$ & $0.07 * * *$ & $0.08 * * *$ & $0.07 * * *$ \\
\hline & {$[2.15]$} & {$[1.87]$} & {$[2.30]$} & {$[1.77]$} & {$[2.20]$} & {$[2.26]$} & {$[2.66]$} & [2.81] & {$[2.78]$} \\
\hline \multirow[t]{2}{*}{ Intercept } & $4.62 * * *$ & $4.62 * * *$ & $3.19 * * *$ & $3.09 * * *$ & $3.14 * * *$ & $3.00 * * *$ & $3.09 * * *$ & $3.10 * * *$ & $3.23 * * *$ \\
\hline & {$[128.79]$} & {$[112.36]$} & {$[12.49]$} & [11.44] & {$[11.77]$} & [9.18] & {$[8.96]$} & [8.92] & [9.16] \\
\hline $\begin{array}{l}\text { Industry } \\
\text { Dummies }\end{array}$ & No & No & No & No & No & No & No & No & No \\
\hline R-sq & 0.002 & 0.003 & 0.055 & 0.061 & 0.066 & 0.067 & 0.073 & 0.073 & 0.079 \\
\hline $\mathrm{N}$ & 2,515 & 1,895 & 1,895 & 1,894 & 1,894 & 1,890 & 1,757 & 1,756 & 1,747 \\
\hline
\end{tabular}




\section{Table 6: Regression Analysis: Determinants of Pay Ratio, adjusted for Industry Effects}

This table presents the regression results where the dependent variable is the natural log of the Pay Ratio. The explanatory variables are described in Table 1. All specifications include a 2018 fiscal year dummy, along with industry dummies based on the Fama-French 48 industry classifications. Panel A presents the base model with panel regressions. Panel B presents the panel regression results where standard errors are clustered by firm. Panel $\mathrm{C}$ also presents panel regressions with standard errors clustered by firm, using the Female*Minority interaction dummy instead of the Minority dummy in the explanatory variables. The sample includes 2017 and 2018 fiscal years for S\&P 1500 firms. T-stats are given in brackets, and *,**,*** stars indicate significance at 10\%, 5\%, and 1\% levels.

Panel A: Base Model with Industry Controls

\begin{tabular}{|c|c|c|c|c|c|c|c|c|c|c|}
\hline & Model 1 & Model 2 & Model 3 & Model 4 & Model 5 & Model 6 & Model 7 & Model 8 & Model 9 & Model 10 \\
\hline \multirow[t]{2}{*}{ Female } & $0.18 *$ & & $0.26^{* *}$ & $0.22 * *$ & $0.22 * *$ & $0.22 * *$ & $0.22 * *$ & $0.22 *$ & $0.23 * *$ & $0.22 *$ \\
\hline & [1.68] & & {$[2.21]$} & {$[2.03]$} & {$[2.02]$} & [1.97] & {$[2.00]$} & [1.91] & [1.97] & [1.87] \\
\hline \multirow[t]{2}{*}{ Minority } & & 0.02 & 0.02 & 0.07 & 0.07 & 0.06 & 0.06 & 0.05 & 0.06 & 0.07 \\
\hline & & {$[0.23]$} & [0.19] & {$[0.68]$} & {$[0.68]$} & {$[0.61]$} & {$[0.62]$} & {$[0.54]$} & {$[0.56]$} & {$[0.68]$} \\
\hline \multirow[t]{2}{*}{ Size } & & & & $0.29 * * *$ & $0.29 * * *$ & $0.29 * * *$ & $0.29 * * *$ & $0.29 * * *$ & $0.28^{* * *}$ & $0.28 * * *$ \\
\hline & & & & [17.90] & [17.89] & [17.91] & [17.63] & [16.45] & [15.94] & [15.46] \\
\hline \multirow[t]{2}{*}{ ROA } & & & & & 0.06 & -0.05 & -0.07 & -0.07 & -0.07 & -0.04 \\
\hline & & & & & {$[0.20]$} & [-0.18] & {$[-0.20]$} & {$[-0.20]$} & {$[-0.21]$} & [-0.11] \\
\hline \multirow[t]{2}{*}{$\mathrm{B} / \mathrm{M}$} & & & & & & $-0.07 *$ & -0.07 & -0.06 & -0.06 & -0.06 \\
\hline & & & & & & [-1.71] & [-1.61] & [-1.38] & {$[-1.35]$} & [-1.32] \\
\hline \multirow[t]{2}{*}{ Tobin's Q } & & & & & & & 0.00 & 0.00 & 0.00 & 0.00 \\
\hline & & & & & & & {$[0.15]$} & {$[-0.01]$} & {$[-0.10]$} & {$[-0.06]$} \\
\hline \multirow[t]{2}{*}{ PCI } & & & & & & & & $-0.02 * *$ & $-0.02 * *$ & $-0.02 * *$ \\
\hline & & & & & & & & {$[-2.54]$} & {$[-2.50]$} & {$[-2.47]$} \\
\hline \multirow[t]{2}{*}{ Duality } & & & & & & & & & 0.08 & $0.10^{*}$ \\
\hline & & & & & & & & & [1.48] & [1.67] \\
\hline \multirow[t]{2}{*}{ Tenure } & & & & & & & & & & 0.00 \\
\hline & & & & & & & & & & {$[-1.00]$} \\
\hline \multirow[t]{2}{*}{ Fiscal Yr-2018 } & 0.03 & 0.03 & 0.03 & 0.02 & 0.02 & 0.03 & 0.03 & 0.03 & 0.04 & 0.03 \\
\hline & {$[0.60]$} & {$[0.63]$} & {$[0.56]$} & {$[0.45]$} & {$[0.43]$} & {$[0.56]$} & {$[0.51]$} & {$[0.64]$} & {$[0.72]$} & {$[0.65]$} \\
\hline Intercept & $4.53 * * *$ & $4.41 * * *$ & $3.88 * * *$ & 1.59 & 1.58 & 1.62 & 1.61 & 1.66 & $1.98 *$ & 1.63 \\
\hline Industry & Led & {$\left[\begin{array}{ll}2.01 \\
\end{array}\right.$} & 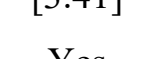 & {$[1.00]$} & {$[1 .+4]$} & 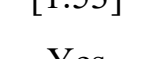 & {$\left[\begin{array}{ll}1.02 \\
U^{2}\end{array}\right.$} & & & \\
\hline Dummies & Yes & Yes & Yes & Yes & Yes & Yes & Yes & Yes & Yes & Yes \\
\hline R-sq & 0.137 & 0.14 & 0.141 & 0.268 & 0.268 & 0.269 & 0.267 & 0.259 & 0.26 & 0.257 \\
\hline $\mathrm{N}$ & 2,502 & 1,896 & 1,885 & 1,885 & 1,884 & 1,884 & 1,880 & 1,747 & 1,746 & 1,737 \\
\hline
\end{tabular}


Panel B: Base Model with Standard Errors Clustered by Firm and Industry Controls

\begin{tabular}{|c|c|c|c|c|c|c|c|c|c|c|}
\hline & Model 1 & Model 2 & Model 3 & Model 4 & Model 5 & Model 6 & Model 7 & Model 8 & Model 9 & Model 10 \\
\hline \multirow[t]{2}{*}{ Female } & 0.18 & & $0.26^{* *}$ & $0.22 * *$ & $0.22 * *$ & $0.22 * *$ & $0.22 * *$ & $0.22 * *$ & $0.23 * *$ & $0.22 *$ \\
\hline & [1.46] & & {$[2.06]$} & {$[2.05]$} & [2.03] & [1.98] & [2.01] & [1.97] & {$[2.01]$} & [1.91] \\
\hline \multirow[t]{2}{*}{ Minority } & & 0.02 & 0.02 & 0.07 & 0.07 & 0.06 & 0.06 & 0.05 & 0.06 & 0.07 \\
\hline & & [0.19] & [0.17] & {$[0.63]$} & {$[0.62]$} & {$[0.56]$} & {$[0.56]$} & [0.49] & {$[0.51]$} & {$[0.62]$} \\
\hline \multirow[t]{2}{*}{ Size } & & & & $0.29 * * *$ & $0.29 * * *$ & $0.29 * * *$ & $0.29 * * *$ & $0.29 * * *$ & $0.28 * * *$ & $0.28 * * *$ \\
\hline & & & & [6.98] & [6.98] & [6.98] & [6.63] & [6.10] & {$[5.55]$} & {$[5.46]$} \\
\hline \multirow[t]{2}{*}{ ROA } & & & & & 0.06 & -0.05 & -0.07 & -0.07 & -0.07 & -0.04 \\
\hline & & & & & {$[0.18]$} & {$[-0.17]$} & {$[-0.23]$} & {$[-0.23]$} & {$[-0.24]$} & {$[-0.12]$} \\
\hline \multirow[t]{2}{*}{$\mathrm{B} / \mathrm{M}$} & & & & & & $-0.07 * *$ & $-0.07 * *$ & $-0.06 * *$ & $-0.06 * *$ & $-0.06 * *$ \\
\hline & & & & & & {$[-2.27]$} & {$[-2.22]$} & {$[-2.02]$} & {$[-2.02]$} & {$[-2.00]$} \\
\hline \multirow[t]{2}{*}{ Tobin's Q } & & & & & & & 0.00 & 0.00 & 0.00 & 0.00 \\
\hline & & & & & & & {$[0.13]$} & {$[-0.01]$} & {$[-0.08]$} & {$[-0.05]$} \\
\hline \multirow[t]{2}{*}{ PCI } & & & & & & & & $-0.02 * * *$ & $-0.02 * * *$ & $-0.02 * * *$ \\
\hline & & & & & & & & {$[-3.19]$} & {$[-3.19]$} & {$[-3.20]$} \\
\hline \multirow[t]{2}{*}{ Duality } & & & & & & & & & 0.08 & 0.10 \\
\hline & & & & & & & & & {$[0.90]$} & {$[1.08]$} \\
\hline \multirow[t]{2}{*}{ Tenure } & & & & & & & & & & 0.00 \\
\hline & & & & & & & & & & {$[-0.97]$} \\
\hline \multirow[t]{2}{*}{ Fiscal Yr-2018 } & 0.03 & 0.03 & 0.03 & 0.02 & 0.02 & 0.03 & 0.03 & 0.03 & 0.04 & 0.03 \\
\hline & {$[1.18]$} & {$[1.31]$} & {$[1.18]$} & {$[0.96]$} & {$[0.92]$} & {$[1.20]$} & {$[1.09]$} & {$[1.38]$} & {$[1.53]$} & {$[1.38]$} \\
\hline \multirow[t]{2}{*}{ Intercept } & $4.53 * * *$ & $4.41 * * *$ & $3.88 * * *$ & $1.59 * * *$ & $1.58 * * *$ & $1.62 * * *$ & $1.61 * * *$ & $1.66 * * *$ & $1.98 * * *$ & $1.63 * * *$ \\
\hline & {$[74.36]$} & {$[1807830.61]$} & [3785166.56] & {$[5.36]$} & {$[5.00]$} & {$[5.16]$} & {$[4.54]$} & {$[4.40]$} & {$[4.76]$} & {$[4.72]$} \\
\hline $\begin{array}{l}\text { Industry } \\
\text { Dummies }\end{array}$ & Yes & Yes & Yes & Yes & Yes & Yes & Yes & Yes & Yes & Yes \\
\hline R-sq & 0.137 & 0.14 & 0.141 & 0.268 & 0.268 & 0.269 & 0.267 & 0.259 & 0.26 & 0.257 \\
\hline $\mathrm{N}$ & 2,502 & 1,896 & 1,885 & 1,885 & 1,884 & 1,884 & 1,880 & 1,747 & 1,746 & 1,737 \\
\hline
\end{tabular}


Panel C: Female and Minority Interaction with Standard Errors Clustered by Firm and Industry Controls

\begin{tabular}{|c|c|c|c|c|c|c|c|c|c|}
\hline & Model 1 & Model 2 & Model 3 & Model 4 & Model 5 & Model 6 & Model 7 & Model 8 & Model 9 \\
\hline \multirow[t]{2}{*}{ Female } & 0.18 & $0.27 * *$ & $0.24 * *$ & $0.24 * *$ & $0.24 * *$ & $0.24 * *$ & $0.24 * *$ & $0.25 * *$ & $0.24 * *$ \\
\hline & [1.46] & [2.04] & [2.11] & [2.08] & {$[2.05]$} & [2.07] & [2.04] & [2.06] & [1.96] \\
\hline \multirow[t]{2}{*}{ Female*Minority } & 0.03 & 0.03 & 0.02 & 0.02 & 0.03 & 0.03 & 0.03 & 0.04 & 0.03 \\
\hline & [1.18] & [1.18] & [0.98] & [0.94] & [1.22] & [1.12] & [1.41] & [1.55] & {$[1.40]$} \\
\hline \multirow[t]{2}{*}{ Size } & & -0.13 & -0.23 & -0.23 & -0.24 & -0.23 & -0.24 & -0.23 & -0.22 \\
\hline & & {$[-0.35]$} & {$[-0.94]$} & {$[-0.94]$} & {$[-1.00]$} & {$[-0.94]$} & {$[-0.96]$} & {$[-0.95]$} & {$[-0.89]$} \\
\hline \multirow[t]{2}{*}{ ROA } & & & $0.29 * * *$ & $0.29 * * *$ & $0.29 * * *$ & $0.29 * * *$ & $0.29 * * *$ & $0.28 * * *$ & $0.28 * * *$ \\
\hline & & & {$[6.96]$} & {$[6.96]$} & {$[6.96]$} & {$[6.61]$} & {$[6.08]$} & {$[5.54]$} & {$[5.45]$} \\
\hline \multirow[t]{2}{*}{$\mathrm{B} / \mathrm{M}$} & & & & 0.06 & -0.05 & -0.07 & -0.08 & -0.08 & -0.05 \\
\hline & & & & [0.19] & {$[-0.17]$} & {$[-0.25]$} & {$[-0.26]$} & {$[-0.27]$} & {$[-0.15]$} \\
\hline \multirow[t]{2}{*}{ Tobin's Q } & & & & & $-0.07 * *$ & $-0.07 * *$ & $-0.06 * *$ & $-0.06 * *$ & $-0.06 * *$ \\
\hline & & & & & {$[-2.31]$} & {$[-2.24]$} & {$[-2.03]$} & {$[-2.04]$} & {$[-2.02]$} \\
\hline \multirow[t]{2}{*}{ PCI } & & & & & & 0.00 & 0.00 & 0.00 & 0.00 \\
\hline & & & & & & {$[0.19]$} & {$[0.05]$} & {$[-0.03]$} & {$[0.01]$} \\
\hline \multirow[t]{2}{*}{ Duality } & & & & & & & $-0.02 * * *$ & $-0.02 * * *$ & $-0.02 * * *$ \\
\hline & & & & & & & {$[-3.18]$} & {$[-3.18]$} & {$[-3.19]$} \\
\hline \multirow[t]{2}{*}{ Tenure } & & & & & & & & 0.08 & 0.10 \\
\hline & & & & & & & & {$[0.89]$} & {$[1.07]$} \\
\hline \multirow[t]{2}{*}{ Fiscal Yr-2018 } & & & & & & & & & 0.00 \\
\hline & & & & & & & & & {$[-0.94]$} \\
\hline \multirow[t]{2}{*}{ Intercept } & $4.53 * * *$ & 3.88 & $1.59 * * *$ & $1.58 * * *$ & $1.62 * * *$ & $1.61 * * *$ & $1.66 * * *$ & $1.98 * * *$ & $1.63 * * *$ \\
\hline & {$[74.36]$} & {$[]$.} & {$[5.35]$} & [4.99] & {$[5.15]$} & {$[4.53]$} & {$[4.39]$} & {$[4.75]$} & {$[4.71]$} \\
\hline $\begin{array}{l}\text { Industry } \\
\text { Dummies }\end{array}$ & Yes & Yes & Yes & Yes & Yes & Yes & Yes & Yes & Yes \\
\hline R-sq & 0.137 & 0.141 & 0.268 & 0.268 & 0.269 & 0.267 & 0.259 & 0.26 & 0.257 \\
\hline $\mathrm{N}$ & 2,502 & 1,885 & 1,885 & 1,884 & 1,884 & 1,880 & 1,747 & 1,746 & 1,737 \\
\hline
\end{tabular}




\section{Table 7: Matched Sample Analysis}

This table presents the results of a paired t-test analysis. Each female CEO in the sample is matched to a male CEO in the same 1-digit SIC code group (Panel A) and Fama-French 48-industry code group (Panel B), with the closest firm size measured as the fiscal year end market value of equity. A paired t-test for comparing the mean pay ratio of the two groups is carried out and the results are presented in the table below. ${ }^{*}, *, * * *$ stars indicate significance at $10 \%, 5 \%$, and $1 \%$ levels.

Panel A: Matched in the same 1-digit SIC code group and firm size

\begin{tabular}{lcccc}
\hline Group & Obs & Mean Pay Ratio & Std. Error & St. Dev. \\
\hline Female & 134 & 373.88 & 72.34 & 837.38 \\
Male & 134 & 174.57 & 20.98 & 242.85 \\
Difference & & 199.31 & 72.92 & 844.14 \\
\hline & & & \\
t-statistic & & $2.73^{* * *}$ & \\
p-value (2-tailed) & & 0.007 & \\
\hline
\end{tabular}

Panel B: Matched in the same Fama-French 48 industry code group and firm size

\begin{tabular}{lcccc}
\hline Group & Obs & Mean Pay Ratio & Std. Error & St. Dev. \\
\hline Female & 133 & 375.71 & 72.86 & 840.27 \\
Male & 133 & 229.23 & 33.17 & 382.49 \\
Difference & & 146.49 & 79.57 & 917.64 \\
\hline & & & \\
t-statistic & & $1.84^{*}$ & & \\
p-value (2-tailed) & 0.068 & & \\
\hline
\end{tabular}




\section{Table 8: Sample of Females Only}

This table presents the analysis of Female CEOs. Panel A reports the mean comparison t-test results comparing the Pay Ratio for Caucasian vs. Minority CEOs within the Female subsample. Panel B reports the regression results where the dependent variable is the natural log of the Pay Ratio. The explanatory variables are described in Table 1. The sample includes 2017 and 2018 fiscal years for S\&P 1500 firms with a Female CEO only. T-stats are given in brackets, and *, **, $* * *$ stars indicate significance at $10 \%, 5 \%$, and $1 \%$ levels.

Panel A: Non-Matched T-Test assuming unequal Variances

\begin{tabular}{lcccc}
\hline Group & Obs & Mean Pay Ratio & Std. Error & St. Dev. \\
\hline Caucasian & 97 & 391.29 & 79.32 & 781.20 \\
Minority & 8 & 207.96 & 87.10 & 246.35 \\
Difference & & 183.33 & 117.80 & \\
\hline t-statistic & 1.56 & & \\
p-value (1-tailed) & & $0.07^{*}$ & & \\
\hline
\end{tabular}

Panel B: OLS Regressions

\begin{tabular}{lcc}
\hline & Model 1 & Model 2 \\
\hline Minority & $-0.82^{*}$ & $-0.82^{*}$ \\
& {$[-1.81]$} & {$[-1.74]$} \\
Size & $0.27^{* * *}$ & $0.27^{* * *}$ \\
& {$[3.56]$} & {$[3.24]$} \\
ROA & -1.57 & -1.57 \\
& {$[-0.62]$} & {$[-0.42]$} \\
B/M & -0.26 & -0.26 \\
& {$[-0.60]$} & {$[-0.53]$} \\
Tobin's Q & 0.17 & 0.17 \\
& {$[1.14]$} & {$[0.84]$} \\
PCI & $-0.51^{* * *}$ & $-0.51^{* * *}$ \\
& {$[-3.21]$} & {$[-4.19]$} \\
Duality & -0.23 & -0.23 \\
& {$[-0.87]$} & {$[-0.79]$} \\
Fiscal Yr-2018 & 0.09 & 0.09 \\
& {$[0.38]$} & {$[0.63]$} \\
Intercept & $2.81^{* * *}$ & $2.81^{* * *}$ \\
& {$[3.36]$} & {$[2.72]$} \\
Clustered St. Errors & No & Yes \\
\hline R-sq & 0.146 & 0.146 \\
$\mathrm{~N}$ & 98 & 98 \\
\hline
\end{tabular}

